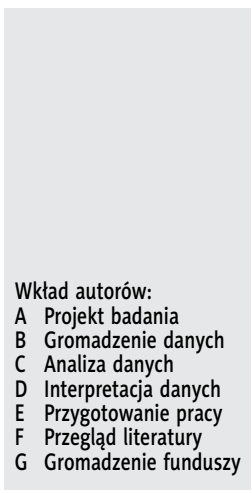

\title{
Przegląd możliwości pomiarowych wybranych systemów do rejestracji emisji otoakustycznych
}

\section{The overview of measurement capabilties of the selected otoacoustic emissions testing systems}

\author{
Bartosz Trzaskowski ${ }^{A B C D E F}$ \\ Instytut Fizjologii i Patologii Słuchu, Światowe Centrum Słuchu, Warszawa/Kajetany
}

\section{Streszczenie}

Na rynku dostępnych jest wiele komercyjnych systemów umożliwiających wykonywanie badań emisji otoakustycznych. Urządzenia te różnią się od siebie przeznaczeniem i funkcjonalnością. Niniejsza praca ma na celu przedstawienie możliwości rejestracji OAE przy użyciu wybranych systemów.

Słowa kluczowe: emisje otoakustyczne • obiektywne badania słuchu • urządzenia medyczne

\section{Abstract}

There are many commercial systems enabling otoacoustic emision testing, which differ in terms of their intended use and functionality. This paper aims to present OAE testing capabilities of the selected systems.

Key words: otoacoustic emissions $\bullet$ objective hearing testing $\bullet$ medical equipment

\section{Wstęp}

Emisje otoakustyczne (ang. Otoacoustic Emissions, OAEs) są to słabe sygnały akustyczne powstające w ślimaku. Pomiary OAE wykonuje się przy użyciu czułego mikrofonu umieszczonego w zewnętrznym kanale słuchowym. Po raz pierwszy zostały zarejestrowane w 1978 r. przez Kempa [1]. OAE pozwalają na monitorowanie funkcji zewnętrznych komórek słuchowych (ang. Outer Hair Cells, OHCs) i nie wymagają współpracy ze strony osoby badanej, dzięki czemu znalazły zastosowanie przy obiektywnej ocenie funkcjonowania ucha wewnętrznego. Obecnie stanowią jedną z najczęściej stosowanych metod obiektywnego badania słuchu. Znajdują zastosowanie w aplikacjach badawczych, klinicznych i przesiewowych. W wielu krajach narodowe programy przesiewowych badań słuchu noworodków oparte są częściowo lub w całości na badaniach OAE.

Mechanizmy generacji emisji otoakustycznych nie zostały jeszcze do końca poznane, ale uważa się, że są one ubocznym efektem nieliniowego mechanizmu odpowiedzialnego za czułość i selektywność częstotliwościową ślimaka, tzw. wzmacniacza ślimakowego, i wynikają z normalnej funkcji zewnętrznych komórek słuchowych. Obecnie przyjmuje się, że są wynikiem złożenia dwóch czynników: emisji nieliniowych zniekształceń związanych bezpośrednio z aktywnością OHC i liniowych odbić związanych z rozpraszaniem fali wędrownej na lokalnych niejednorodnościach w impedancji ślimaka $[2,3]$.

Najogólniej, emisje otoakustyczne można podzielić na emisje wywołane bodźcem słuchowym (ang. Evoked Otoacoustic Emissions, EOAEs) i emisje spontaniczne (ang. Spontaneous Otoacoustic Emissions, SOAEs). Te ostatnie, w odróżnieniu od emisji rejestrowanych w odpowiedzi na podawane bodźce akustyczne, powstają w ślimaku bez podania bodźca i przyjmuje się, że występują u ok. 50\% dzieci i dorosłych ze słuchem normalnym [4]. Różnice w doniesieniach na temat tego odsetka wahają się pomiędzy $40 \%$ [5] a $72 \%$ [6], jednak ze względu na jego wartość, emisje spontaniczne nie znalazły zastosowania jako badanie użyteczne klinicznie.

Emisje wywołane można podzielić ze względu na rodzaj bodźca słuchowego na trzy grupy. Emisje otoakustyczne wywołane tonem (ang. Stimulus Frequency Otoacoustic Emissions, SFOAE) są rejestrowane jako odpowiedzi o składowych tej samej częstotliwości co podawany 
w sposób ciągły bodziec tonalny. Obecnie SFOAE są wykorzystywane głównie jako metoda badawcza, a nie kliniczna i bardzo niewiele urządzeń posiada możliwość ich rejestracji. W zastosowaniach diagnostycznych i przesiewowych stosowane są dwa pozostałe rodzaje emisji. Emisje otoakustyczne wywołane krótkimi bodźcami (ang. Transient-Evoked Otoacoustic Emissions, TEOAEs) to najdłużej znany rodzaj emisji, odkryty przez Kempa [1]. Ze względu na rodzaj bodźca podzielić je można na emisje otoakustyczne wywołane trzaskiem (ang. Click-Evoked Otoacoustic Emissions, CEOAEs) i krótkimi tonami (ang. Toneburst-Evoked Otoacoustic Emissions, TBOAEs). W tej grupie emisji odpowiedzi rejestrowane są po zakończeniu bodźca i zależą istotnie od charakterystyk pobudzenia. Odpowiedzi wywołane krótkimi tonami wywołują odpowiedzi bardziej specyficzne częstotliwościowo, jednak najczęściej stosowanym bodźcem jest trzask o widmie pozwalającym na pobudzenie błony podstawnej w szerokim zakresie częstotliwości. Bodźce te przeważnie podawane są w trybie nieliniowym - naprzemiennie trzy bodźce o polaryzacji dodatniej i jeden o trzykrotnie większej amplitudzie o polaryzacji ujemnej. W założeniu, taki rodzaj pobudzenia powinien umożliwić przede wszystkim rejestrację nieliniowej części odpowiedzi. Po uśrednieniu wystarczającej liczby pojedynczych odpowiedzi, zarejestrowane zapisy są poddawane analizie całościowej oraz w wybranych pasmach częstotliwości. Parametrami uwzględnianymi przy ocenie wyniku są powtarzalność pojedynczych rejestracji, poziom odpowiedzi i stosunek sygnału do szumu (ang. Signal-to-Noise Ratio, SNR) całościowo lub w określonych pasmach częstotliwości.

Ostatnim rodzajem emisji otoakustycznych są emisje produktów zniekształceń nieliniowych (ang. Distortion-Product Otoacoustic Emissions, DPOAEs) [7,8] wywoływane dwoma jednocześnie podawanymi bodźcami tonalnymi o częstotliwościach $f_{1}$ i $f_{2}$ i odpowiednio dobranych poziomach. Odpowiedź rejestrowana jest dla konkretnej częstotliwości, najczęściej $2 f_{1}-f_{2}$, i określana na podstawie oszacowania stosunku sygnału do szumu. W zastosowaniach klinicznych najczęściej wykorzystywane są wykresy poziomów DPOAE i szumu w funkcji częstotliwości $f_{2}$ bodźca, tzw. DP-gramy lub funkcje wejścia-wyjścia (ang. DPOAE I/O).

Najczęściej stosowanymi klinicznie typami OAE są emisje otoakustyczne wywołane trzaskiem i emisje produktów zniekształceń nieliniowych. Są jednak prace pokazujące, że w przypadku niektórych badań lepsze wyniki mogą być uzyskane przy wykorzystaniu kombinacji różnych typów emisji [9] lub innych protokołów, np. opartych na liniowym trzasku [10]. Wynik badania czy to przesiewowego, czy diagnostycznego może więc zależeć między innymi od połączenia metod, typu emisji otoakustycznych, protokołu czy parametrów pomiaru. Nawet w przypadku zastosowania jednego protokołu wciąż można spodziewać się niewielkich różnic $\mathrm{w}$ wynikach $\mathrm{w}$ zależności od użytego systemu lub sondy $[11,12]$.

Obecnie na rynku dostępnych jest wiele systemów przeznaczonych specjalnie do pomiarów emisji otoakustycznych lub posiadających taką opcję dodatkowo. Urządzenia te mają zróżnicowaną funkcjonalność. Niniejsza praca ma na celu przedstawienie możliwości rejestracji emisji otoakustycznych oferowanych przez wybrane systemy.

\section{Urządzenia do badań emisji otoakustycznych}

Pierwszą klasą urządzeń do pomiarów emisji otoakustycznych są urządzenia przeznaczone do przesiewowych badań słuchu. Najczęściej są to niewielkie urządzenia ręczne, oferujące znaczną automatyzację pomiarów i ograniczone możliwości ingerencji w ustawienia parametrów. Systemy te przeważnie dostarczają wyniki w postaci niewymagającej interpretacji. Druga klasa to urządzenia przeznaczone do zastosowań diagnostycznych lub badawczych, posiadające znacznie większe możliwości konfiguracji parametrów pomiaru i prezentacji, przetwarzania oraz analizy wyników.

\section{GN Otometrics A/S}

Przykładem systemu z pierwszej grupy może być Madsen Alpha OAE firmy GN Otometrics A/S [13]. Urządzenie pozwala na wykonywanie przesiewowych badań DPOAE w trybie automatycznym. Testowane są częstotliwości: 5, 4, 3 i $2 \mathrm{kHz}$, a końcowym wynikiem badania jest wskazanie „PASS” lub „REFER” wraz z wykresem słupkowym pokazującym poziomy sygnału i szumu. Domyślnym kryterium jest obecność odpowiedzi w przynajmniej trzech spośród czterech badanych częstotliwości. Badanie zatrzymuje się automatycznie w momencie, gdy trzy częstotliwości zostaną oznaczone jako PASS lub dwie jako REFER.

Trochę większe możliwości posiada urządzenie Madsen Accuscreen tej samej firmy [14]. Dostępne jest w wariantach pozwalających na wykonywanie dowolnej kombinacji badań: ABR, TEOAE i DPOAE. Zostało ono zoptymalizowane dla niemowląt w wieku do 6 miesięcy. Może być wykorzystane do badań osób starszych, jednak w przypadku tej grupy należy oczekiwać dłuższych czasów badań i większego odsetka wyników dodatnich. AccuScreen posiada 4 różne protokoły do rejestracji DPOAE:

1. Częstotliwości: 5, 4, 3, 2 kHz, kryterium PASS/REFER: trzy z czterech częstotliwości. Badanie jest przerywane, gdy trzy częstotliwości zostaną oznaczone jako PASS lub dwie jako REFER. Jest to protokół domyślny.

2. Częstotliwości: 6, 5, 4, 3,5, 3, 2 kHz, kryterium PASS/REFER: cztery z sześciu częstotliwości. Badanie jest przerywane, gdy cztery częstotliwości zostaną oznaczone jako PASS lub trzy jako REFER.

3. Częstotliwości: 4, 3, 2, 1 kHz, kryterium PASS/REFER: trzy z czterech częstotliwości. Wszystkie częstotliwości są badane.

4. Częstotliwości: 6, 5, 4, 3, 2, 1 kHz, kryterium PASS/REFER cztery z sześciu częstotliwości. Wszystkie częstotliwości są badane.

Inne protokoły mogą być załadowane do urządzenia za pomocą oprogramowania AccuLink. Badania TEOAE wykonywane są przy użyciu bodźca w postaci nieliniowej sekwencji trzasków dla zakresu częstotliwości 1,5-4,5 kHz. Podobnie jak w Alpha OAE automatycznie dostarczane są wyniki badania przesiewowego niewymagające dodatkowej interpretacji.

Trzecim urządzeniem tego producenta, zrealizowanym we współpracy z firmą Intelligent Hearing Systems, jest Madsen Capella ${ }^{2}$ [15]. Jest to system diagnostyczny o nieporównywalnie większych możliwościach konfiguracyjnych. Pozwala na pomiary TEOAE, DPOAE i SOAE. 
DPOAE mogą być mierzone dla częstotliwości w przedziale 500-10 $000 \mathrm{~Hz}$ z krokiem zmiany $1 \mathrm{~Hz}$, dla poziomu bodźca 0-75 dB SPL w zależności od częstotliwości, zmiennym co $1 \mathrm{~dB}$. Dla zaawansowanych użytkowników istnieje możliwość ręcznego konfigurowania kombinacji badanych częstotliwości w DPOAE, zapewniając praktycznie nieskończoną liczbę punktów pomiarowych na oktawę. TEOAE mogą być wywoływane bodźcami typu trzask lub krótkie tony dla natężeń 40-90 dB SPL w zakresie 450$5000 \mathrm{~Hz}$. SOAE rejestrowane są jako zsynchronizowane SOAE (ang. Synchronized Spontaneous Otoacoustic Emissions, SSOAE) dla natężeń bodźca 40-60 dB SPL i określane w sposób automatyczny na podstawie stosunku sygnału do szumu. Urządzenie przedstawia wyniki badań w rozbudowanej formie. Mogą one być dowolnie analizowane $\mathrm{w}$ dziedzinie czasu i częstotliwości oraz porównywane $\mathrm{z}$ wynikami $\mathrm{z}$ historii pacjenta. Jest to przykład urządzenia $z$ drugiej grupy systemów o dużej funkcjonalności, dedykowanych do zastosowań diagnostycznych lub badawczych.

\section{Grason-Stadler}

Producent Grason-Stadler posiada aktualnie w swojej ofercie trzy urządzenia do pomiarów emisji otoakustycznych. Pierwszy z tych systemów - Corti [16] umożliwia pomiary DPOAE i TEOAE. Oferuje sześć opcji konfiguracyjnych pozwalających na dopasowanie możliwości urządzenia do potrzeb kliniki: trzy opcje do badań przesiewowych i trzy opcje do badań diagnostycznych. Opcje przesiewowe umożliwiają pomiary DPOAE, TEOAE lub DPOAE + TEOAE. Konfiguracje diagnostyczne oferują diagnostykę DPOAE, TEOAE lub DPOAE + TEOAE oraz dodatkowo definiowalne protokoły badań przesiewowych. Jednostki przesiewowe mają możliwość ulepszenia do konfiguracji diagnostycznych. W zależności od konfiguracji i typu badania urządzenie posiada odmienną funkcjonalność:

Badania diagnostyczne DPOAE:

- 4 konfigurowalne protokoły,

- czas uśredniania: 4 sekundy na częstotliwość,

- częstotliwości: od 1,5 do $12 \mathrm{kHz}$,

- maksymalna liczba częstotliwości w jednym badaniu: 12 ,

- możliwe do wyboru natężenia: 40-70 dB SPL,

- możliwe do wyboru SNR: 3-10 dB,

- możliwe do wyboru czasy uśredniania: 0,5, 1, 2, 4 s,

- możliwe do wyboru liczby częstotliwości dla wskazania PASS: 0-6,

- kryteria wskazania PASS: konfigurowalne.

Badania przesiewowe DPOAE w konfiguracjach diagnostycznych:

- 1 ustalony protokół,

- częstotliwości: 2, 3, 4, $5 \mathrm{kHz}$,

- natężenia L1/L2: 65/55 dB,

- SNR: $6 \mathrm{~dB}$,

- kryteria wskazania PASS: w 3 częstotliwościach: SNR 6 $\mathrm{dB}$,

- czas uśredniania: $4 \mathrm{~s}$.

Badania przesiewowe DPOAE w konfiguracjach przesiewowych:

- 2 ustalone protokoły,
- częstotliwości: 2, 3, 4, $5 \mathrm{kHz}$

- natężenia L1/L2: 65/55 dB,

- SNR: $6 \mathrm{~dB}$,

- kryteria wskazania PASS: w 3 częstotliwościach: SNR $6 \mathrm{~dB}$,

- czas uśredniania: 2 i 4 s.

Badania diagnostyczne TEOAE:

- 2 konfigurowalne protokoły,

- częstotliwości: od 0,7 do $4 \mathrm{kHz}$,

- możliwe do wyboru SNR: 3-10 dB,

- możliwe do wyboru czasy uśredniania: 8, 16, 32 i 64 s,

- możliwe do wyboru liczby częstotliwości dla wskazania PASS: 0-6,

- kryteria wskazania PASS: konfigurowalne.

Badania przesiewowe TEOAE w konfiguracjach diagnostycznych:

- 1 ustalony protokół,

- pasma częstotliwości: 1,5, 2, 2,5, 3, 3,5, $4 \mathrm{kHz}$,

- SNR: $4 \mathrm{~dB}$,

- kryteria wskazania PASS: w 3 częstotliwościach SNR $4 \mathrm{~dB}$,

- maksymalny czas uśredniania: $64 \mathrm{~s}$.

Badania przesiewowe TEOAE w konfiguracjach przesiewowych:

- 2 ustalone protokoły,

- pasma częstotliwości: 1,5, 2, 2,5, 3, 3,5, $4 \mathrm{kHz}$,

- SNR: $4 \mathrm{~dB}$,

- kryteria wskazania PASS: w 3 częstotliwościach SNR $4 \mathrm{~dB}$,

- maksymalny czas uśredniania: 32 i 64 s.

Drugi system Grason-Stadler, GSI AUDIOscreener+ [17] jest urządzeniem przesiewowym łączącym możliwość pomiaru emisji otoakustycznych oraz słuchowych potencjałów wywołanych pnia mózgu (ang. Auditory Brainstem Responses, $A B R$ ). Możliwy jest wybór urządzenia w jednej z trzech konfiguracji:

- do badań OAE/ABR pozwalającej na rejestrację TEOAE i DPOAE oraz ABR,

- do badań OAE umożliwiającej pomiary TEOAE i DPOAE,

- tylko do badań ABR.

AUDIOscreener+ pozwala na pomiary DPOAE w zakresie częstotliwości od 2000 do $6000 \mathrm{~Hz}$ z rozdzielczością $50 \mathrm{~Hz}$. Posiada zautomatyzowane kryteria przesiewowe oparte na SNR i poziomie odpowiedzi. Są one ustawione zgodnie z protokołem NIH 2000 i mogą być konfigurowane przez użytkownika. TEOAE są analizowane w zakresie częstotliwości od 250 do $5250 \mathrm{~Hz}$ z rozdzielczością $50 \mathrm{~Hz}$. Zautomatyzowane kryteria przesiewowe oparte są na SNR i powtarzalności odpowiedzi.

Urządzenie zostało zaprojektowane do obsługi przez niewykwalifikowany personel i nie wymaga interpretacji danych. Wciśnięcie przycisku wykonuje automatycznie badanie przesiewowe i prezentuje wynik w postaci oznaczenia PASS/REFER. Jednocześnie istnieje możliwość programowania badanych częstotliwości (5 par częstotliwości dla DPOAE i 5 pasm dla TEOAE) przez wyszkolony personel. Ograniczone dane diagnostyczne OAE i ABR są zbierane 
przez urządzenie w celu zmniejszenia częstości występowania klasyfikacji fałszywych dodatnich i fałszywych ujemnych. Dane te mogą następnie zostać odczytane przez wykwalifikowany personel lub przesłane w celu konsultacji.

Trzecim system do pomiarów OAE w ofercie Grason-Stadler jest GSI Audera [18]. Pozwala na badanie słuchowych potencjałów wywołanych, emisji otoakustycznych i słuchowych potencjałów wywołanych stanu ustalonego (ang. Auditory Steady State Response, ASSR). W ramach badań emisji otoakustycznych można rejestrować DPO$\mathrm{AE}$, emisje spontaniczne i funkcje wejścia-wyjścia DPOAE. System posiada zdefiniowane protokoły: domyślny diagnostyczny i przesiewowy, które mogą być konfigurowane przez użytkownika. Umożliwia analizę DP-gramów, I/O-gramów, wykresów FFT i wartości SNR w wybranych punktach oraz porównywanie wyników.

DPOAE może być badane w zakresie częstotliwości 500-12 $000 \mathrm{~Hz}$. Poziom może być regulowany w przedziale 20-80 dB SPL, w 5-dB krokach. Zakresy oktaw to: $500-1000,1000-2000,2000-4000,4000-8000$ i 8000-12 $000 \mathrm{~Hz}$. Liczba punktów na oktawę może wynosić od 1 do 12 . Stosunek częstotliwości f2/f1 może być: $1,1-1,8$. Ułatwieniem $\mathrm{w}$ interpretacji wyników jest możliwość porównania do danych normatywnych.

\section{Intelligent Hearing Systems}

System SmartScreener-Plus 2 [19] firmy Intelligent Hearing Systems jest rozwiązaniem przeznaczonym do badań przesiewowych noworodków. Oferuje możliwość wyboru opcji: automatycznych badań przesiewowych ABR, badań przesiewowych OAE lub obydwu. Posiada możliwość dodania opcjonalnie diagnostycznych badań ABR (SmartEP) oraz diagnostycznych badań OAE (SmartOAE [20] i SmartTrOAE [21]). Urządzenie jest proste w obsłudze i nie wymaga specjalnych umiejętności technicznych ani interpretacji wyników przez operatora urządzenia. Rozwiązaniem sprzętowym wykorzystywanym w tym systemie jest platforma USBLite. Urządzenie pozwala na ocenę emisji otoakustycznych przy wykorzystaniu TEOAE lub DPOAE. Zaimplementowany jest pięcioczęstotliwościowy protokół przesiewowych badań DPOAE oraz pięciopasmowy TEOAE, jednak mogą być one ustawiane przez użytkownika poprzez zabezpieczone hasłem funkcje administratora, umożliwiające pełną kontrolę nad protokołami i parametrami.

Firma Intelligent Hearing Systems posiada w swojej ofercie dwa systemy przeznaczone do przesiewowych i diagnostycznych badań emisji otoakustycznych osób w każdym wieku: SmartOAE [20] i SmartTrOAE [21].

SmartOAE służy do wykonywania badań DPOAE. System prezentuje DP-gramy i szczegółowe informacje dla każdej z badanych częstotliwości. Dostarcza także jednoznacznych wskazań PASS/REFER opartych na kryteriach wybranych przez użytkownika. Istnieje możliwość wyświetlenia na DP-gramie zakresów normatywnych, co ułatwia ocenę wyniku. Parametry badania i kryteria zatrzymania mogą być konfigurowane przez użytkownika. System umożliwia oglądanie wyników dla obojga uszu różnicowanych za pomocą kolorów lub obok siebie na jednym ekranie. Można także wyświetlić dane dla wszystkich punktów w postaci tabelarycznej.

SmartOAE może być używany z każdą platformą sprzętową tej firmy. Badania przesiewowe i diagnostyczne DPO$\mathrm{AE}$ mogą być wykonywane przy wykorzystaniu modułów: USB Lite, USB Jr. i USB Box. Platformy USB Jr. i USB Box pozwalają na wykonywanie I/O DPOAE, a platforma USB Box posiada dodatkowo możliwość badania wysokich częstotliwości w zastosowaniach badawczych i ograniczonych klinicznych. Wszystkie trzy platformy wykorzystują sondę 10D OAE, a w przypadku modułu USB Box istnieje możliwość użycia mikrofonu 10B+ OAE przy zastosowaniu zewnętrznego stymulatora.

Urządzenie ma wiele cech przydatnych w zastosowaniach badawczych, takich jak np. pomiary do wysokich częstotliwości - $16 \mathrm{kHz}$ w przypadku ludzi i $32 \mathrm{kHz}$ w przypadku zwierząt, funkcja wejścia-wyjścia (DP-IO) czy DPOAE Scripting - opcja dająca możliwość zaprogramowania badania DPOAE za pomocą pliku skryptowego.

System udostępnia także uproszczony tryb ustawień własnych, który wymaga określenia tylko zakresu częstotliwości oraz liczby badanych częstotliwości na oktawę. Poziomy bodźca, stosunek częstotliwości $f_{1} / f_{2}$, poziom odrzucania artefaktów i liczba pojedynczych rejestracji mogą być określane przez użytkownika w sposób dowolny. Poziom odrzucania artefaktów może być automatycznie dostosowywany do warunków panujących w czasie pomiaru.

SmartTrOAE to system do pomiarów TEOAE. Umożliwia badania standardowych TEOAE wywołanych trzaskiem oraz emisji spontanicznych. Wyniki automatycznie oznaczane są jako PASS lub REFER. W przypadku platformy USB Box istnieje możliwość ciągłego maskowania szumem ucha przeciwnego do badanego oraz możliwość dodania opcjonalnego modułu „Ipsilateral Suppression”. W ramach wsparcia zastosowań badawczych, system posiada możliwość wykonywania analiz czasowo-częstotliwościowych i szczegółowej interpretacji charakterystyk widmowych oraz graficznej prezentacji ich wyników.

SmartTrOAE również może być używany z każdą platformą sprzętową tej firmy. Badania przesiewowe i diagnostyczne TEOAE oraz emisji spontanicznych mogą być wykonywane przy użyciu modułów: USB Lite, USB Jr. i USB Box. Platforma USB Box pozwala dodatkowo na maskowanie ucha przeciwnego i badania supresji ipsilateralnej. Moduł USB Box przy wykorzystaniu zewnętrznego stymulatora pozwala na użycie mikrofonu 10B OAE. Tak samo jak w przypadku SmartOAE, dopuszczalne jest rozszerzenie możliwości pomiarowych o dodatkowe funkcjonalności oferowane przez producenta. Moduły będą wówczas wykorzystywać jedną zintegrowaną bazę danych pacjentów i jeden wspólny mechanizm tworzenia raportów.

\section{Interacoustics}

System OtoRead [22] firmy Interacoustics to urządzenie ręczne, które może być wykorzystywane jako przesiewowe lub diagnostyczne. Dostępny jest w sześciu wersjach licencjonowanych oddzielnie, różniących się możliwościami badań. Posiada kilkanaście protokołów dla TEOAE 
i DPOAE dostępnych w zależności od wybranego wariantu licencji. Trzy licencje przesiewowe mają ustalone protokoły, natomiast trzy licencje przeznaczone do badań klinicznych pozwalają dodatkowo na konfigurowanie protokołów predefiniowanych.

Licencja Screener DP pozwala na badanie DPOAE w zakresie od 2 do $5 \mathrm{kHz}$. Kryterium dla wyniku PASS to przynajmniej trzy spośród czterech testowanych częstotliwości z SNR powyżej $6 \mathrm{~dB}$. Przy licencji Screener TE badane są TEOAE w zakresie od 1,5 do $4 \mathrm{kHz}$. Kryterium dla oznaczenia PASS to 3 z 6 częstotliwości z SNR powyżej $4 \mathrm{~dB}$. Ostatnia z licencji przesiewowych - Screener+ oferuje połączenie możliwości pomiarowych obu wcześniej przedstawionych licencji.

W trzech licencjach przeznaczonych do badań klinicznych: poziomy bodźca, czasy badania, liczba testowanych częstotliwości oraz progowa wartość SNR do oznaczenia PASS wszystkie mogą być ustawiane przez użytkownika. Licencja Standard TE pozwala na badania TEOAE w przedziale częstotliwości $0,7-4 \mathrm{kHz}$, a licencja Standard DP na badania DPOAE w przedziale 1,5-12 kHz. W przypadku obu tych licencji, różne częstotliwości mogą być wybrane i wszystkie parametry protokołów mogą być zmienione. Licencja Clinical DP \& TE łączy w sobie funkcjonalność obydwu licencji klinicznych. Protokoły rozszerzone pozwalają na badanie do sześciu częstotliwości, aż do $12 \mathrm{kHz}$ w modelu DPOAE. Protokoły DPOAE/TEOAE mogą być ustawione przy użyciu standardowych lub własnych kryteriów PASS/REFER. Zakres natężenia bodźca przy pomiarach DPOAE wynosi: od $40 \mathrm{~dB}$ do $70 \mathrm{~dB}$ SPL. Pomiary TEOAE wykonywane są przy $83 \mathrm{~dB}$ SPL $( \pm 3 \mathrm{~dB})$.

System Eclipse [23] producenta Interacoustics pozwala na pomiary: AEP, ASSR, VEMP i OAE jednak funkcjonalność urządzenia jest zależna od wyboru dedykowanych modułów sprzętowych. Do pomiarów emisji otoakustycznych przeznaczone są moduły DPOAE20 i TEOAE25.

Moduł DPOAE20 pozwala na badania DPOAE wywoływanych bodźcami w zakresie częstotliwości $500-8000 \mathrm{~Hz}$, o natężeniu od $30 \mathrm{~dB}$ do $75 \mathrm{~dB}$ SPL (70 dB dla częstotliwości powyżej $6 \mathrm{kHz}$ ). Oprogramowanie wyświetla szczegółowe DP-gramy dla protokołów predefiniowanych lub zaprojektowanych przez użytkowników oraz wykresy funkcji wejścia-wyjścia DP. Umożliwia tworzenie własnych zbiorów danych normatywnych lub korzystanie z norm dostarczonych przez producenta. Możliwe jest także ręczne nadpisanie długości badania.

Moduł TEOAE25 do wywołania emisji otoakustycznych wykorzystuje liniowe lub nieliniowe trzaski o szerokości pasma 400-4000 Hz i natężeniu w przedziale 50-90 dB SPL. Czas badania może być regulowany w zakresie 25-32 000 pojedynczych rejestracji (ang. sweeps). Szeroka gama opcji klinicznych zapewnia pełną kliniczną ocenę TEOAE. Oprogramowanie umożliwia analizę widmową, wyświetlanie poziomu odpowiedzi i odstępu SNR. TEOAE25 umożliwia ustawienia protokołu do automatycznego wyświetlania wyników PASS/REFER w badaniach przesiewowych słuchu. Dostępne są także predefiniowane ustawienia fabryczne. Szerokość pasm do kryteriów oznaczeń PASS/REFER wynosi $1 \mathrm{kHz}$, możliwość wyświetlania 1/3,
1/6, 1/12-oktawowych pasm. W celu potwierdzenia detekcji OAE wykonywane są testy istotności. Poziomy czułości i odrzucania hałasu również mogą być kontrolowane przez użytkownika.

Trzeci system z oferty firmy Interacoustics - Titan [24] może być dostosowany do wykorzystania w celach przesiewowych, diagnostycznych i zaawansowanych badań klinicznych. W zależności od wyboru programowych modułów urządzenie może być używane do badań impedancji, ABR, OAE i wykonywania tympanometrii szerokopasmowej.

\section{Dostępne są cztery moduły:}

IMP440 - dostępny w wersji diagnostycznej przesiewowej i klinicznej. Umożliwia standardowe badania tympanometyczne, odruchów ipsi- i kontralateralnych, zanikanie odruchu, a także trzy testy funkcji trąbki słuchowej.

ABRIS440 - umożliwia szybkie automatyczne testowanie ABR dla niemowląt i dorosłych. Moduł wykorzystuje bodziec CE-Chirp ${ }^{\oplus}$ i wagi Bayesa, co umożliwia skrócenie czasu badania o $50 \% \mathrm{w}$ porównaniu $\mathrm{z}$ tradycyjnymi bodźcami typu trzask.

DPOAE440 - dostępne są dwie różne wersje DPOAE w zależności od potrzeb klinicznych: przesiewowa - do badania słuchu noworodków i zaawansowana diagnostyka - umożliwiająca wykonywanie pomiarów DPOAE pod ciśnieniem, co jest przydatne podczas badania niemowląt przy warunkach panujących w uchu środkowym. Funkcjonalność przesiewowa pozwala na wykonywanie pomiarów w maksymalnie sześciu częstotliwościach z zakresu $500-6000 \mathrm{~Hz}$ oraz wykreślenie DP-gramu. Protokoły mogą być definiowane przez użytkownika i istnieje możliwość włączenia wskazań PASS/REFER. Dane normatywne mogą być przeglądane i edytowane oraz importowane lub eksportowane. Opcja kliniczna pozwala na badanie nieograniczonej liczby częstotliwości z przedziału 500-10 $000 \mathrm{~Hz}$ oraz dodatkowo umożliwia pomiar funkcji wejścia-wyjścia.

TEOAE440 - dostępne są dwie wersje badań TEOAE. Wersja przesiewowa oferuje dużą szybkość pomiaru, precyzję i łatwość obsługi. Umożliwia badania w zakresie częstotliwości 1000-4500 Hz dla natężenia bodźca 60-84 dB SPL. Czas pomiaru ograniczony jest do 6 minut lub do 4500 pojedynczych rejestracji. Częstotliwości środkowe pasm wynoszą 1, 1,5, 2, 3 i $4 \mathrm{kHz}$. Możliwe jest włączenie wskazań PASS/REFER oraz definiowanie protokołów przez użytkownika. Dane normatywne mogą być importowane i eksportowane oraz zmieniane. Wersja kliniczna zapewnia większą elastyczność, udostępniając centralny, liniowy lub w pełni konfigurowalny zakres częstotliwości do pełnej diagnostyki lub zastosowań badawczych. Pozwala na pomiary w zakresie częstotliwości $500-5500 \mathrm{~Hz}$ dla natężenia bodźca 30-90 dB SPL. Urządzenie umożliwia rejestrację dowolnej liczby pojedynczych odpowiedzi. Poza funkcjonalnością modułu przesiewowego, system pozwala dodatkowo na definiowanie przez użytkownika własnych pasm częstotliwości, wyświetlanie FFT oraz rozszerzony ręczny tryb badania.

Moduły mogą być dodawane w miarę potrzeb w trakcie użytkowania urządzenia. 


\section{Labat International}

System EchoLab firmy Labat International [25] pozwala na wykonywanie badań w trybie przesiewowym oraz klinicznym. Jest to urządzenie ręczne, umożliwiające pracę $\mathrm{z}$ ładowanego akumulatora. Możliwe badania to: TEOAE, DPOAE, przesiewowe ABR, automatyczne ABR (AABR). Badania AABR używają opcjonalnego przedwzmacniacza. Badania supresji są możliwe z opcjonalnymi słuchawkami wewnątrzusznymi do podawania szumu. Łączność z komputerem odbywa się za pomocą specjalnego oprogramowania umożliwiającego pobieranie danych pacjenta, wykonywanie wydruków oraz przesyłanie protokołów badań. Protokoły mogą być programowane przez użytkownika.

Do rejestracji TEOAE wykorzystywane są bodźce liniowe i nieliniowe. Zakres badanych częstotliwości jest od 1000 do $5000 \mathrm{~Hz}$, z rozdzielczością $50 \mathrm{~Hz}$. Poziom bodźca może być ustawiany w zakresie 0-90 dB SPL z dokładnością $\pm 2 \mathrm{~dB}$ SPL.

System pozwala na badania DPOAE dla częstotliwości od 250 do $10000 \mathrm{~Hz}$. Rozdzielczość w częstotliwości jest programowalna i może wynosić 5, 10 lub $25 \mathrm{~Hz}$. Poziom bodźca może być ustawiany w zakresie 0-90 dB SPL.

\section{MAICO Diagnostics}

System ERO•SCAN Plus [26] firmy MAICO Diagnostics jest dostępny w dwóch wersjach: przesiewowej i diagnostycznej. ERO•Scan z funkcją badań przesiewowych jest zalecany do zastosowań w programach przesiewowych badań słuchu lub w przypadku konieczności szybkiej oceny systemu ślimakowego na podstawie dostarczanych wyników PASS lub REFER. Urządzenie może być używane do badań osób w każdym wieku, ale jest rozwiązaniem przeznaczonym szczególnie do badań przesiewowych noworodków, niemowląt i dzieci w wieku przedszkolnym. Posiada dwa protokoły przeznaczone do badań przesiewowych DPOAE i dwa do TEOAE. DPOAE mogą być rejestrowane dla częstotliwości z zakresu $2-5 \mathrm{kHz}$, przy natężeniu bodźca 65/55 dB. TEOAE mogą być badane dla częstotliwości 1,5-4 kHz dla natężenia bodźca $83 \mathrm{~dB}$ SPL.

ERO•Scan w wersji diagnostycznej umożliwia bardziej zaawansowane zastosowania. System ten jest przeznaczony dla pediatrów, ale został również dostosowany do szczególnych potrzeb otologów, audiologów i otolaryngologów. Dostarcza obiektywnych informacji o stanie słuchu i umożliwia określenie funkcji komórek włosowych zewnętrznych $\mathrm{w}$ ślimaku na podstawie jednego badania. Urządzenie posiada 5 protokołów diagnostycznych DPOAE i 3 protokoły diagnostyczne TEOAE, z których 4 dla DPOAE i 2 dla TEOAE są konfigurowalne. Możliwość wykonywania badań TEAOE jest dostępna jako opcja rozbudowy systemu, a możliwości pomiarowe zależą od wybranej konfiguracji. DPOAE mogą być rejestrowane dla częstotliwości 1,5-12 kHz, dla natężenia bodźca 40-70 dB SPL, z czasem uśredniania 0,5, 1, 2 lub 4 sekundy. TEOAE można badać dla częstotliwości $0,7-4 \mathrm{kHz}$, przy natężeniu bodźca $83 \mathrm{~dB}$, dla czasu uśredniania 8, 16, 32 lub 64 sekundy. Urządzenie wykonuje badania szybko i w sposób automatyczny, a wynik wyświetlany jest w postaci graficznej lub jednoznacznych wskazań PASS/REFER niewymagających interpretacji.
Drugi system firmy MAICO Diagnostics do pomiaru OAE - ERO•SCAN Pro [27] to ręczne urządzenie umożliwiające także badania tympanometryczne. Został zaprojektowany do szybkiego i automatycznego badania słuchu noworodków, dzieci i dorosłych. Jest przeznaczony do gabinetów oraz klinik otolaryngologicznych. Wszystkie badania zaczynają się autostartem. Wyniki dla maksymalnie 12 częstotliwości są wyświetlane jako widok SNR lub wykres wartości. Możliwe są wyniki: PASS, REFER, NOISY i SEAL.

Podobnie jak w przypadku systemu ERO•SCAN [26], dostępne są dwie wersje urządzenia: przesiewowa i diagnostyczna, a możliwości pomiarowe zależą od wybranej konfiguracji. Wersja przesiewowa posiada dwa ustalone protokoły do pomiaru DPOAE dla czterech częstotliwości z zakresu 2-5 kHz i natężenia bodźca 65/55 dB SPL oraz dwa stałe protokoły TEOAE dla częstotliwości 1,5-4 kHz i natężenia bodźca $83 \mathrm{~dB}$ SPL.

Wersja diagnostyczna posiada 1 ustalony protokół do badań przesiewowych DPOAE oraz 20 protokołów badań diagnostycznych, z czego 4 są konfigurowalne. DPOAE mogą być rejestrowane dla 10 częstotliwości $\mathrm{z}$ zakresu 1,5-12 kHz, przy natężeniu bodźca 40-70 dB SPL. Urządzenie posiada 1 ustalony protokół przesiewowego badania TEOAE oraz 20 protokołów diagnostycznych, wliczając 2 protokoły w pełni konfigurowalne. Badane mogą być odpowiedzi dla częstotliwości z przedziału $0,7-4 \mathrm{kHz}$, dla natężenia bodźca $83 \mathrm{~dB}$ SPL.

Podobnie jak ERO•SCAN, system ERO•SCAN Pro występuje w konfiguracjach: DPOAE, TEOAE i DPOAE+TEOAE.

\section{Mimosa Acoustics}

Przenośne urządzenie Otostat [28] firmy Mimosa Acoustics umożliwia przesiewowe i diagnostyczne badania ucha wewnętrznego za pomocą emisji produktów zniekształceń nieliniowych (DPOAE) oraz badania charakterystyk ucha środkowego (ang. Middle-Ear Power Analysis, MEPA). Pozwala na pomiar DPOAE w częstotliwości $2 f_{1}-f_{2}$ z zakresu $1000-8000 \mathrm{~Hz}$. Stosunek częstotliwości $f_{2} / f_{1}$ wynosi 1,2 , a poziomów bodźców L1/L2: 65/55 dB SPL. Zaimplementowane są 3 protokoły kliniczne, wykorzystujące 4, 6, lub 12 częstotliwości testowych. Dane normatywne dla każdej grupy wiekowej ułatwiają ocenę badania i interpretację wyniku. System umożliwia określenie zasad zatrzymania dla obu wyników (PASS i REFER), dzięki czemu pozwala zaoszczędzić czas podczas badań dorosłych i dzieci. Czas badania jednej częstotliwości waha się od 2 do 6 sekund.

System diagnostyczny układu słuchowego Mimosa Acoustics HearID [29] oferuje różne metody oceny stanu ucha środkowego i ucha wewnętrznego. Łączy elektronikę pozwalającą na rejestrację danych z wysokiej czułości sondą ER10C firmy Etymotic Research o niskim szumie. Urządzenie wymaga do pracy komputera, a główną jednostkę przetwarzającą audio podłącza się do standardowego portu USB2 w komputerze przenośnym. Oprogramowanie HearID zapewnia dostęp do dokumentacji pacjenta, zapisów historii badania i modułów umożliwiających pomiary, m.in.: reflektancji (MEPA3), DPOAE, TEOAE, SSOAE, SFOAE i odruchu układu oliwkowo-ślimakowego 
przyśrodkowego (ang. Medial-Olivocochlear Reflex Module, MOCR).

HearID pozwala na badania przesiewowe i diagnostyczne ucha środkowego i wewnętrznego osób w każdym wieku przy użyciu jednej dopasowanej sondy.

Badania DPOAE mogą być przeprowadzane w dwóch trybach: przesiewowym i zaawansowanym. Można badać do 50 punktów na oktawę w zakresie częstotliwości 500-16 $000 \mathrm{~Hz}$. W systemie zdefiniowane są następujące punkty DP: $f_{2}-f_{1} ; 2 f_{2}-f_{1} ; 2 f_{1}-f_{2} ; 3 f_{1}-2 f_{2} ; 3 f_{2}-2 f_{1} ; 4 f_{1}-3 f_{2} ; 4 f_{2}-3 f_{1}$. Zakres poziomu bodźców: 0-70 dB SPL. Zaprogramowane są protokoły pomiarów dla 4 i 6 częstotliwości protokołów Boystown oraz dla 6 i 12 częstotliwości w celu przejrzystego zestawienia. Protokoły pomiarów mogą być konfigurowane przez użytkownika. System wspiera zasady zatrzymania i wyposażony jest $\mathrm{w}$ bazę danych normatywnych ułatwiających ocenę wyniku.

Pomiary TEOAE mogą być wykonywane w trybie badawczym lub klinicznym. System umożliwia zastosowanie bodźców typu trzask lub chirp w kilku różnych wariantach oraz regulacji szerokości pasmowej, czasu trwania, poziomu, wyboru białego lub różowego widma i polaryzacji bodźca. Odstęp pomiędzy bodźcami jest także regulowany i możliwy jest wybór pomiędzy liniowymi i nieliniowymi trybami podawania bodźca. Urządzenie wyposażone jest $\mathrm{w}$ gotowe zaprogramowane protokoły pomiarów. Pozwala też na zapisywanie ulubionych protokołów pod własnymi nazwami. Filtry dolno- i górnoprzepustowe odpowiedzi oraz szerokość okna akwizycji mogą być regulowane. Możliwe jest użycie ustawianego przez użytkownika graficznego poziomu odrzucania szumu lub zastosowanie opcjonalnego trybu automatycznego. System dostarcza jednoznacznych wskazań wyniku PASS/REFER i umożliwia ich konfigurację. Zasady zatrzymania pozwalają zakończyć badanie wcześniej przy osiagnięciu wyniku PASS. Zasady szerokopasmowe i wąskopasmowe mogą być konfigurowane indywidualnie. System umożliwia także pomiar synchronizowanych spontanicznych emisji otoakustycznych (SSOAE).

Badania SFOAE w urządzeniu HearID sa dostepne dzięki modułowi SF i dedykowane są dla klientów badawczych. W urządzeniu zaimplementowane zostały protokoły zgodne z [30]. Protokoły badań SFOAE są elastyczne i konfigurowalne. Częstotliwości badawcze mogą być równomiernie rozmieszczone w sposób liniowy, logarytmicznie lub potegowo i skupione w pobliżu kluczowych czestotliwości. Grupowanie pozwala na to, żeby opóźnienie grupowe SFOAE było oszacowane efektywnie bez konieczności pomiaru całego widma. Spośród wszystkich rodzajów pomiarów OAE, SFOAE zapewniają najbardziej bezpośredni i wyraźny pomiar składowej OAE związanej z odbiciem, która jest uważana za najmocniej narażoną na uszkodzenia ślimakowe [31].

Dla użytkowników badawczych dostępny jest również dla modułu SF kontralateralny dodatek stymulatora. Generuje on cyfrowy szerokopasmowy szum lub ton, synchronizuje wyjście z pomiarami SFOAE, $w$ tym programowalne przesunięcia uwzględniające opóźnienia, i automatycznie zapisuje pliki danych ze wspólnym przedrostkiem nazw plików. Ten dodatek jest tylko programowy - odpowiednia karta dźwiękowa i skalibrowane słuchawki muszą być zapewnione niezależnie.

\section{Natus}

Systemy firmy Natus: AuDX Pro, AuDX Pro II, AuDX Pro Plus [32-34] to przenośne urządzenia do badań DPOAE i TEOAE przeznaczone dla wszystkich grup wiekowych, wyposażone w kolorowy wyświetlacz i przyjazne użytkownikowi oprogramowanie. W wyniku badania dostarczaja jednoznacznych oznaczeń PASS/REFER.

AuDX Pro jest przeznaczony do stosowania w programach UNHS, szkołach i ośrodkach podstawowej opieki zdrowotnej. Oferuje tryby badań przesiewowych DPOAE lub TEOAE, w tym protokół badań przesiewowych dorosłych, który pozwala uniknąć nadmiernej liczby wyników REFER związanych z protokołami pediatrycznymi. Załączone jest oprogramowanie do konfiguracji protokołów. Pamięć urządzenia jest w stanie pomieścić 50 badań.

AuDX Pro II jest przeznaczony dla audiologów i lekarzy otorynolaryngologów lub osób potrzebujących systemu o większej elastyczności. Względem AuDX Pro załączone są trzy dodatkowe protokoły DPOAE, w tym protokół dla osób dorosłych oraz AuDX-Scout Link umożliwiający pobieranie danych AuDX do wersji odczytowej aplikacji Scout na komputerze PC w celu przeglądania i drukowania danych. Pamięć urządzenia mieści 100 badań.

AuDX Pro Plus łączy możliwości przenośnych badań przesiewowych i diagnostyki komputerowej. Oprócz opcji dostępnych w AuDX Pro II dostarcza dodatkowo funkcjonalność rejestracji danych w oprogramowaniu Scout.

System Echo-Screen III [35] tego samego producenta, to urzadzenie przesiewowe $\mathrm{z}$ dużym ekranem dotykowym i klawiaturą QWERTY do badań TEOAE, DPOAE i ABR. Urządzenie jest dostępne $\mathrm{w}$ dowolnej kombinacji najczęściej wykorzystywanych funkcji - TEOAE, DPOAE oraz ABR - zapewniając użytkownikom te narzędzia do wykonywania przesiewowych badań słuchu, które są w danym momencie potrzebne. Istnieje możliwość rozbudowy urządzenia o dodatkowe funkcjonalności. Możliwości pomiarów TEOAE i DPOAE zależą od konfiguracji. Urządzenie to, jako przeznaczone do badań przesiewowych, jest w pełni zautomatyzowane i posiada wstępnie ustawione standardowe parametry. Wyniki przedstawiane są automatycznie w postaci wskazań PASS/REFER i nie wymagają interpretacji. System używa tych samych sprawdzonych i zaufanych algorytmów wraz z automatycznymi, wstępnie ustalonymi parametrami badań przesiewowych, które zostały użyte $\mathrm{w}$ wielu programach przesiewowych. Przeznaczony jest do badań pacjentów w każdym wieku.

Urządzenie ABaer [36] firmy Natus jest systemem przesiewowym typu „wszystko w jednym”, wykorzystywanym w badaniach noworodków. Umożliwia badania: ABR, DPOAE i TEOAE w różnych kombinacjach. Dostępne sa wersje: ABR, ABR + TEOAE, ABR + DPOAE, ABR + TEOAE + DPOAE. Charakteryzuje go szybka i prosta obsługa oraz zautomatyzowane wyniki PASS/REFER. Dzięki wstępnie ustawionym parametrom przesiewowym nie 
jest konieczna konfiguracja użytkownika. Samouczki wideo dostarczają pomocnych wskazówek, jak przeprowadzić badanie przesiewowe. Predefiniowane konfiguracje DPOAE umożliwiają wykonanie specyficznego częstotliwościowo badania przesiewowego dla częstotliwości: 2, 3, 4 i $5 \mathrm{kHz}$. System umożliwia wewnątrzuszną kalibrację bodźca i sprawdzenie stabilizacji sondy przed badaniem. Funkcjonalność TEOAE pozwala na badanie częstotliwości w zakresie od 1,2 do 3,5 kHz. Kontrola dopasowania sondy może odbywać się podczas badania. Czasy pomiarów są krótkie i wynoszą około 10 sekund na jedno ucho.

\section{Neurosoft}

Neuro-Audio-Screen [37] firmy Neurosoft to przesiewowy system ręczny do badań OAE i ABR, przeznaczony do diagnostyki słuchu noworodków. Dostępny jest w dwóch wariantach. Neuro-Audio-Screen umożliwia pomiary: ABR, TEOAE i DPOAE, a Neuro-Audio-Screen/OAE umożliwia pomiary: TEOAE i DPOAE. System pozwala na wprowadzenie danych dziecka, kontrolę procesu badania i zapis wyników do bazy danych. Według producenta, urządzenie to może być zaliczone do klasy urządzeń diagnostycznych ze względu na możliwość wykonywania badań w trybie eksperckim. Ustawienia testowe mogą być zmieniane za pomocą menu konfiguracyjnego. Można użyć różnych trybów badania emisji otoakustycznych, np. „Screening”, „Noisy (screening)". System pomaga szybko dostosować ustawienia w celu wykonania dowolnego testu, począwszy od badań przesiewowych słuchu w hałaśliwym pomieszczeniu, po ekspertyzy w specjalistycznym szpitalu.

System Neuro-Audio [38] tej firmy posiada większe możliwości i umożliwia zastosowanie zarówno przesiewowe, jak i diagnostyczne. Przeznaczony jest do obiektywnych badań słuchu noworodków, dzieci i dorosłych. W urządzeniu udostępniona jest większość testów potrzebnych w codziennej praktyce audiologicznej.

Neuro-Audio pozwala na badanie:

- słuchowych potencjałów wywołanych z pnia mózgu (ABR),

- słuchowych potencjałów stanu ustalonego ASRR z możliwością równoczesnej stymulacji w 4 częstotliwościach dla obojga uszu (multi-ASSR),

- emisji otoakustycznych OAE (TEOAE, DPOAE, SOAE),

- słuchowych potencjałów słuchowych (AEP: MLR, LLR),

- przedsionkowych miogennych potencjałów wywołanych (VEMP),

- audiometrii tonalnej (PTA),

- elektrokochleografii (ECochG),

- poznawczych potencjałów wywołanych (MMN, P300).

Badania DPOAE i TEOAE można wykonywać także w trybie przesiewowym. W tym trybie do wykonania badań wymagane jest minimum oddziaływania $\mathrm{z}$ urządzeniem, ponieważ oprogramowanie podpowiada kolejne kroki lub wykonuje je w sposób automatyczny. Wyniki zostają wyświetlone w postaci wskazania PASS lub REFER. Technicy mogą zostać łatwo przeszkoleni do wykonywania badań przesiewowych. Dostępny jest także 12-punktowy tryb DPOAE, o częstotliwościach do $12 \mathrm{kHz}$. Dostęp do wszystkich ustawień wzmacniaczy, stymulatorów i opcji przetwarzania sygnałów pozwala na tworzenie własnych szablonów niestandardowych badań dla potrzeb badań naukowych. Producent zapewnia, że w przypadku braku pewnej elastyczności lub funkcji można skontaktować się bezpośrednio z potężnym zespołem inżynierów firmy.

\section{Otodynamics}

System Echoport ILO288 [39,40] firmy Otodynamics to wszechstronny system OAE, przeznaczony do badań przesiewowych i klinicznych osób w każdym wieku. Jest to najbardziej popularny na świecie komputerowy system do badań emisji otoakustycznych. Posiada predefiniowane automatyczne protokoły przesiewowe i może dostarczać automatycznie wyniki badań przesiewowych niewymagające interpretacji. Umożliwia konfigurację przez użytkownika czterech protokołów do badań przesiewowych i diagnostycznych. Posiada automatyczne ustawienia rozpoczęcia i zatrzymania badania oraz konfigurowalne kryteria PASS dla każdego trybu. System dostępny jest w dwóch wersjach. Wersja ILO288-I jest urządzeniem do badań TEOAE, szczególnie nadającym się do zastosowania $\mathrm{w}$ narodowych programach przesiewowych. Wersja ILO288-II jest urządzeniem przesiewowym do badań TEOAE i DPOAE. Sprawdzona metoda rejestracji TEOAE - ILO Quickscreen dobrze nadaje się do badań przesiewowych i klinicznych. Umożliwia badania częstotliwości z zakresu 1-4 kHz. Poziom bodźców typu trzask jest konfigurowalny. System ma możliwość wyświetlania pasmowych wskazań PASS/REFER opartych na kryteriach. Opcja analizy DP-gramów jest dostępna w ILO288-II. Można badać odpowiedzi DPOAE do częstotliwości 8 kHz. Użytkownik ma możliwość wyboru poziomów bodźców i liczby punktów na oktawę, włączając opcję utworzenia wysokiej rozdzielczości DP-gramu do 8 punktów, przy wyświetlaniu wyników dla 27 częstotliwości.

System Echoport ILO292 [41,42] firmy Otodynamics jest dostępny również w dwóch modelach. Echoport ILO292-I oferuje pełen zakres badań klinicznych w tym: TEOAE, DPOAE, SOAE i DP-Growth. Echoport ILO292-II to zaawansowany system do klinicznych obustronnych pomiarów OAE $\mathrm{z}$ oprogramowaniem ILOV6. Pozwala badać: TEOAE, DPOAE, SOAE, DP-Growth, obuuszne TEOAE i DPOAE oraz supresję kontralateralną. Posiada predefiniowane automatyczne protokoły przesiewowe oraz ustawienia rozpoczęcia i zatrzymania badania. Może dostarczać wyniki niewymagające interpretacji. Protokoły badań i kryteria PASS mogą być dowolnie konfigurowane przez użytkownika.

Pomiary TEOAE są możliwe przy wykorzystaniu metody Quickscreen oraz standardowej rejestracji diagnostycznej ILO o oknie akwizycji 20 ms. Dostępne są bodźce trzask lub konfigurowalne impulsy tonowe. Natężenie stymulacji może być regulowane, a kalibracja przeprowadzana jest w uchu. Bodziec i dopasowanie sondy są monitorowane w czasie rzeczywistym. System umożliwia analizę ILO wykorzystującą poziomy OAE w dB SPL i parametry powtarzalności w półoktawowych pasmach częstotliwości. Posiada również zaimplementowane skuteczne wyszukiwanie SSOAE w celu wykrycia rzeczywistych i ukrytych składowych emisji spontanicznych. W przypadku modelu Echoport ILO292-II możliwa jest jednoczesna obustronna rejestracja TEOAE. 
Opcja DPOAE umożliwia tworzenie wysokorozdzielczych DP-gramów - do 8 punktów na oktawę. System posiada ustawienia wstępne parametrów bodźców, ale pozwala też na ich konfigurację. Programowalne są poziomy L1 i L2, częstość podawania bodźca, liczba punktów na oktawę, zakres częstotliwości, ręczna/automatyczna/inteligentna progresja częstotliwości, analiza funkcji wejścia/wyjścia, tempa wzrostu i ocena całkowitej mocy DP. Model Echoport ILO292-II umożliwia jednoczesną obustronną rejestrację. Wyświetlanie pełnego widma podczas badania pokazuje DPOAE wyższego rzędu.

System udostępnia szeroki zestaw narzędzi analitycznych. Umożliwia jednoczesną ocenę i porównanie funkcji dla kombinacji DP-DP, TE-DP i TE-TE. Pozawala na ocenę pełnych cross-korelacji, analizę częstotliwościową, powtarzalności i stosunku sygnału do szumu dla danych z pojedynczego badania lub między parami badań. Możliwa jest analiza zapisu przebiegu $\mathrm{z}$ wydobyciem odpowiedzi i szczegółowa analiza widma TEOAE $\mathrm{z}$ rozdzielczością $50 \mathrm{~Hz}$ oraz półoktawowe oszacowanie mocy OAE. Wyniki mogą być prezentowane w pełni numerycznych tabelach danych.

Firma Otodynamics oferuje również serię ręcznych urządzeń do pomiarów OAE Otoport [43]. Poszczególne modele różnią się od siebie funkcjonalnością i przeznaczeniem.

System Otoport Advance [44] jest przeznaczony do wszystkich zastosowań klinicznych i przesiewowych oraz badań diagnostycznych. Posiada szerokie możliwości przetwarzania i zaawansowanej analizy danych. Umożliwia badania DPOAE i TEOAE.

Zaawansowany DP-gram pozwala na badanie DPOAE w zakresie częstotliwości $1-8 \mathrm{kHz}$, od 2 do 16 punktów na oktawę, 1-13 częstotliwości. Standardowy DP-gram zawiera 6 punktów, z przedziału $1-8 \mathrm{kHz}$ i do 2 punktów na oktawę. Możliwe jest przybliżenie (DP Zoom) aż do pasma półoktawowego i do rozdzielczości 16 punktów na oktawę. Częstotliwości bodźców $f_{1}$ i $f_{2}$ są programowalne, podobnie jak ich natężenie w zakresie 40-75 dB SPL. System umożliwia także badanie funkcji wejścia-wyjścia DPOAE.

W badaniach TEOAE możliwe jest wykorzystanie metody QuickScreen z analizą „ILO”. Urządzenie wyświetla przebieg sygnału, poziomy w dB SPL, SNR i parametry powtarzalności. Dostępna jest analiza półoktawowa z zakresu częstotliwości $1-6 \mathrm{kHz}$, w 6 pasmach. Widmo jest prezentowane $\mathrm{w}$ wysokiej rozdzielczości, o minimalnej szerokości pasma $80 \mathrm{~Hz}$.

System umożliwia konfigurowanie wyświetlania znaczników zakresu danych normatywnych. Wyposażony jest w potężne narzędzia odrzucania artefaktów. Posiada 12 trybów badań, w tym $10 \mathrm{w}$ pełni konfigurowalnych. Umożliwia sprawdzanie dopasowania sondy w czasie rzeczywistym i wyświetlanie dokładności. Wspiera konfigurowalne zasady zatrzymania badania oparte na jakości odpowiedzi lub klinicznych kryteriach wskazań PASS/REFER.

Model Otoport DP+TE [45] to uniwersalny system do przesiewowych i klinicznych badań DPOAE i TEOAE przeznaczony dla pacjentów w każdym wieku. Jest szybki, łatwy w obsłudze i prosty w konfiguracji. Posiada zoptymalizowany tryb pediatryczny. Umożliwia badania TEOAE w zakresie od 1-4 kHz przy wykorzystaniu metody QuickScreen oraz pozwala na wykonanie DP-gramów w zakresie 1-8 kHz w dwóch trybach: 12 konfigurowalnych częstotliwości lub 4 punktów na oktawę. Prezentuje wyniki w postaci wskazań PASS/REFER całkowitych i w półoktawowych pasmach lub szczegółowo wyświetla parametry OAE w numerycznych tabelach. Znaczniki zakresu normatywnego mogą być konfigurowane.

System umożliwia natychmiastowy wybór trybu DPOAE lub TEOAE na początku badania. Pozwala na konfigurowanie kryteriów wskazań PASS dla 2, 3, 4 lub 5 częstotliwości w badaniach DPOAE i dla 2, 3 lub 4 półoktawowych pasm w przypadku TEOAE. System ma opcję automatycznego startu szybkiego badania przesiewowego i tryb inteligentny zarządzania badaniem w celu szybszego wykonywania pomiarów. Odrzucanie szumu dla aktualnych warunków otoczenia jest konfigurowalne.

Model Otoport Lite [46] dostępny jest poza Ameryką Północną. Jest to prosty w użyciu przenośny system OAE $\mathrm{z}$ intuicyjnym interfejsem. Otoport Lite jest dostępny w dwóch wariantach: TEOAE lub DPOAE. Dedykowany jest do badań przesiewowych TEOAE noworodków lub do badań przesiewowych noworodków i badań pediatrycznych DPOAE.

Wybór modelu TEOAE pozwala badać emisje otoakustyczne w przedziale $1-4 \mathrm{kHz}$ dla 5 pasm częstotliwości, przy użyciu 3 trybów przesiewowych i metody Quickscreen. Posiada konfigurowalne kryterium 6 dB SNR w 2, 3 lub 4 pasmach półoktawowych lub całej odpowiedzi, przy szerokich lub wąskich pasmach. Model DPOAE pozwala badać 4 punkty częstotliwości z przedziału $2-6 \mathrm{kHz}$ i konfigurację kryterium $6 \mathrm{~dB}$ SNR w 2, 3 lub 4 częstotliwościach.

System jest automatyczny i prosty w obsłudze. Prezentuje wyniki w postaci wskazań PASS/REFER, umożliwiając wybór wyświetlania całościowego lub dla pasm częstotliwości. Wyświetla także ostrzeżenia w przypadku złego dopasowania sondy, wysokiego poziomu hałasu lub dzwonienia bodźca.

Otodynamics oferuje również systemy będące rozszerzeniem modeli: Otoport Advance, Otoport DP+TE i Otoport Lite o możliwość rejestracji słuchowych potencjałów wywołanych pnia mózgu. Dostępne są one jako gotowe rozwiązania łączące dany model ze sprzętowym modułem ABR lub jako opcja rozszerzenia posiadanego urządzenia o funkcjonalność ABR poprzez dokupienie modułu.

System Otoport DP+TE OAE+ABR [47] to rozwiązanie dedykowane do badań klinicznych OAE z możliwością badań przesiewowych OAE i ABR, przeznaczone dla pacjentów w każdym wieku. Umożliwia szczegółowe oraz szybkie, zautomatyzowane badania przesiewowe TEOAE i DPOAE. Analiza dopasowania sondy i hałasu przeprowadzana jest w sposób automatyczny. Kryteria oznaczeń PASS są konfigurowalne, umożliwiając wykorzystanie 2, 3, 4 lub 5 częstotliwości w badaniach DPOAE i 2, 3 lub 4 półoktawowe pasma w przypadku TEOAE. System wyświetla histogram sygnału i szumu ze wskazaniami PASS/REFER 
w pasmach częstotliwości i zapis przebiegu TEOAE. Pozwala na wykonanie konfigurowalnego 12-punktowego DP-gramu w zakresie częstotliwości $1-8 \mathrm{kHz}$ oraz umożliwia badanie TEOAE metodą QuickScreen w zakresie 1-4 kHz. Udostępnia cztery tryby przeprowadzania badań. Protokoły badań są programowalne.

System składa się z urządzenia Otoport DP+TE lub Otoport Advance umieszczonych w module umożliwiającym badania ABR. Moduł ten może być także dokupiony do obu modeli urządzenia oddzielnie w celu dodania funkcjonalności ABR.

W przypadku modelu Advance, możliwe jest dodatkowo wykonywanie analizy widmowej, analizy DPOAE w powiększeniu do 16 punktów na oktawę, badanie funkcji wejścia-wyjścia DPOAE i możliwość badania sześciu półoktawowych pasm w zakresie 1-6 kHz w TEOAE.

Otoport OAE+ABR Lite Model [48] to ręczny, przenośny system przeznaczony do przesiewowych badań OAE i ABR noworodków. Funkcjonalność OAE pozwala na przeprowadzanie automatycznych badań przesiewowych OAE, konfigurację kryteriów PASS/REFER, SNR dla: 2, 3 lub 4 częstotliwości. Tryb DPOAE umożliwia badanie 4 częstotliwości z zakresu 2-6 kHz, a TEOAE - 5 pasm półoktawowych w przedziale $1-4 \mathrm{kHz}$. Dokładna analiza jest dostępna za pośrednictwem pakietu oprogramowania Otolink do zarządzania i pełnego śledzenia wyników badań na podstawie surowych danych. Użytkownicy modelu Otoport Lite mają możliwość rozszerzenia urządzenia do tej wersji systemu poprzez dokupienie modułu do badań ABR.

Otoport OAE+ABR Upgrade [49] to zautomatyzowany system do badań przesiewowych OAE i ABR dla pacjentów w każdym wieku, umożliwiający analizę DPOAE i TEOAE uważaną za złoty standard. Umożliwia wykonanie DP-gramu w zakresie częstotliwości $1-8 \mathrm{kHz}$ dla 12 konfigurowalnych częstotliwości lub dla 4 punktów na oktawę, oraz badania TEOAE częstotliwości $1-4 \mathrm{kHz}$ przy wykorzystaniu metody ILO QuickScreen. Wyświetlacz w sposób intuicyjny pokazuje postęp SNR i wskaźniki poziomu OAE i szumu oraz wskazania PASS/REFER dla pasm półoktawowych. Wyniki mogą być prezentowane w postaci tabel numerycznych poziomu sygnału, szumu i SNR. Wskaźniki wyświetlania zakresu normatywnego są programowalne.

Na samym początku badania możliwy jest wybór trybu badania OAE: DPOAE lub TEOAE. Urządzenie posiada dwa tryby bodźca: DP high i DP low oraz konfigurowalne poziomy. System posiada konfigurowalne kryteria wskazań PASS DPOAE dla 2, 3, 4 lub 5 częstotliwości oraz 2, 3 lub 4 półoktawowe, szeroko- lub wąskopasmowe kryteria PASS dla TEOAE. Opcja automatycznego startu znajduje zastosowanie przy szybkich testach przesiewowych. Poziom odrzucania szumu z otoczenia może być konfigurowany.

Otoport Screener [50] to model polecany do dużych programów UNHS. System posiada bazę danych i możliwości konfiguracyjne. Umożliwia przeprowadzanie przesiewowych badań TEOAE przy wykorzystaniu popularnej w wielu krajach od 1990 r. metody QuickScreen dla 5 częstotliwości w przedziale 1-4 kHz. Urządzenie wyświetla półoktawowy histogram TEOAE oraz tabele $\mathrm{z}$ wartościami numerycznymi parametrów OAE.

System posiada 4 tryby przesiewowe, regulowane kryteria oznaczeń PASS/REFER, w pełni konfigurowalne protokoły oraz statystyki programu UNHS poprzez oprogramowanie EZ-Screen. Umożliwia szczegółową analizę przebiegu czasowego odpowiedzi. Emisje wywoływane są nieliniowym szerokopasmowym bodźcem trzask, o natężeniu 60-90 dB SPL p.e., podawanym z częstością $80 \mathrm{~Hz}$. System pozwala na regulację odrzucania artefaktów w zakresie 40-74 dB SPL. Okno czasowe rejestracji odpowiedzi jest w przedziale 3-13 ms. Umożliwia półoktawową widmową analizę w czasie rzeczywistym nieliniowej składowej OAE w zakresie 1-4 kHz oraz automatyczną ocenę dopasowania sondy z opcją kalibracji ręcznej. Użytkownik może wykorzystać opcję automatycznych oznaczeń PASS/REFER, ręcznej konfiguracji kryteriów na podstawie SNR w 2, 3 lub 4 pasmach częstotliwości lub wykrywania całkowitego braku odpowiedzi. Oprogramowanie do zarządzania danymi z badań Otolink i EZ-Screen PC jest dostarczane wraz $\mathrm{z}$ urządzeniem.

Ostatni system firmy Otodynamics z tej serii to urządzenie Otocheck LE [51]. Jest to szybkie, niedrogie i proste urządzenie przeznaczone do badań przesiewowych OAE noworodków i dzieci w trudnych warunkach środowiskowych, gdzie nie ma wymogu przechowywania danych testowych. Minimalizuje liczbę instrukcji i posiada zaledwie 7 przycisków sterujących. System charakteryzuje się prostą obsługą "press-and-go". Prezentuje wyniki w postaci jednoznacznych wskazań PASS/REFER. Umożliwia wybór wyników całkowitych lub dla pasm częstotliwości w modelu TEOAE. Posiada ostrzeżenia złego dopasowania sondy i wysokiego poziomu hałasu. Posiada tryb szybki, odporny na hałas i wyposażony jest w intuicyjny wyświetlacz graficzny pokazujący postęp SNR. Występuje w dwóch wersjach. Model TEOAE przeznaczony jest do badań dla noworodków. Umożliwia badanie OAE w zakresie $1-4 \mathrm{kHz}$ przy użyciu metody QuickScreen dla 5 pasm częstotliwości w zakresie 1-4 kHz. Posiada konfigurowalne kryteria oznaczeń PASS - 6 dB SNR w 2, 3 lub 4 półoktawowych pasmach, w zakresie 1-3 kHz lub dla całej odpowiedzi. Model DPOAE, przeznaczony do zastosowań w pediatrii, posiada tryb szybki - badanie 4 częstotliwości z zakresu 2-6 kHz. Zawiera konfigurowalne kryteria oznaczeń PASS oparte na odstępie SNR 6 dB dla 2, 3 lub 4 częstotliwości zoptymalizowane do stosowania $\mathrm{w}$ pediatrii.

\section{PATH medical GmbH}

Sentiero Desktop [52] firmy PATH medical GmbH to kompaktowy system posiadający możliwość wykonywania badań: audiometrii tonalnej i słownej, TEOAE, DPOAE, tympanometrii i odruchów strzemiączkowych. Emisje otoakustyczne mogą być mierzone w obu uszach równocześnie. Jest odpowiedni dla pacjentów w każdym wieku, ale wyposażony jest też w zoptymalizowany tryb pediatryczny.

Posiada szybkie i diagnostyczne protokoły testowe DPOAE, umożliwiając badania częstotliwości od 1 do $10 \mathrm{kHz}$, w wysokiej rozdzielczości - aż do 30 punktów na oktawę oraz pozwalające na oszczędność czasu, badanie FMDPOAE (ang. Frequency Modulated DPOAE). Umożliwia 
wykonanie opatentowanego przez firmę oszacowania progu słyszenia DPOAE do $50 \mathrm{~dB}$ HL w zakresie częstotliwości: od 1,5 do $8 \mathrm{kHz}$. Poziom bodźców jest w tym badaniu w zakresie od $20 \mathrm{~dB}$ HL do $65 \mathrm{~dB}$ HL. Urządzenie posiada także szybkie i diagnostyczne tryby testowe TEOAE dla zakresu od 0,7 do $4 \mathrm{kHz}$ z pasmami półoktawowymi z wielokrotnymi kryteriami zatrzymania i ustawieniami SNR.

\section{Vivosonic Inc.}

Integrity V500 [53] firmy Vivosonic to przenośny, bezprzewodowy system umożliwiający wykonywanie diagnostycznych i automatycznych przesiewowych badań DPOAE i TEOAE. Technologia bezprzewodowej rejestracji VivoLink automatycznie pobiera dane kalibracji sondy OAE i wykonuje test systemu przed rozpoczęciem badania pacjenta, reguluje poziom bodźca i wykonuje pomiary OAE. Wyświetla jednoznaczne wskazania PASS/REFER lub szczegółowe wyniki OAE. Kryteria wskazań PASS/REFER są wielokrotne, elastyczne i konfigurowalne przez użytkownika.

DPOAE mogą być wywoływane bodźcami dla częstotliwości $f_{2}: 0,5,0,75,1,1,5,2,2,5,3,3,2,3,5,4,4,5,5,5,5,6$, 7, $8 \mathrm{kHz}$ o poziomach: $40-75 \mathrm{~dB}$ SPL. Stosunek częstotliwości $f_{2} / f_{1}$ może wynosić 1,2 i 1,22 . Mierzone są sygnał DPOAE, szum i SNR.

TEOAE wywoływane są liniowymi lub nieliniowymi bodźcami trzask $80,120 \mu$ s, o natężeniu w przedziale 60-85 dB pe SPL. Mierzone są wartości sygnału, szumu, stosunku SNR w paśmie $1 \mathrm{kHz}$ i pasmach 1, 1/2, 1/4, 1/6-oktawowych.

\section{Podsumowanie}

W niniejszej pracy przedstawione zostały możliwości pomiarowe 34 systemów do badań emisji otoakustycznych dostępnych na rynku. Zestawienie uwzględnia aktualną ofertę 12 producentów. Przedstawione zostały urządzenia o bardzo zróżnicowanej funkcjonalności, przeznaczone dla osób w różnym wieku i do różnych zastosowań, począwszy od programów przesiewowych słuchu noworodków, po badania diagnostyczne w warunkach klinicznych.

Wszystkie systemy oferowały możliwości pomiarów emisji otoakustycznych u dzieci, a w szczególności u niemowląt.
Część urządzeń, szczególnie tych przeznaczonych do badań przesiewowych, wyposażono w zoptymalizowane pediatryczne tryby badań. Niektóre posiadały protokoły przeznaczone dla dorosłych, pozwalające uniknąć nadmiernej liczby wyników dodatnich związanych z protokołami pediatrycznymi. Funkcje omówionych urządzeń zebrane zostały w tabeli 1. Praktycznie wszystkie przedstawione systemy umożliwiały pomiary dwóch typów OAE, najczęściej wykorzystywanych w badaniach przesiewowych i diagnostycznych: TEOAE i DPOAE. Możliwości pomiarowe TEOAE i DPOAE wybranych urządzeń zestawione zostały w tabeli 2. Opcje pomiaru SOAE, SFOAE lub wsparcie zastosowań badawczych w omówionych systemach były rzadkością.

Połowę opisanych systemów stanowiły urządzenia przeznaczone wyłącznie do pomiarów emisji otoakustycznych, jednak pozostałe umożliwiały wykonywanie także innych badań słuchu, takich jak: słuchowe potencjały wywołane (w szczególności ABR i ASSR), tympanometria czy audiometria tonalna lub słowna.

Urządzenia przeznaczone do badań przesiewowych posiadały predefiniowane protokoły, umożliwiały szybkie i proste wykonanie pomiarów oraz prezentowały wyniki w postaci wskazań PASS/REFER, które nie wymagały interpretacji. Urządzenia przeznaczone do zastosowań diagnostycznych przeważnie umożliwiały regulację parametrów rejestracji w szerszym zakresie oraz pozwalały na szczegółową analizę odpowiedzi i wybór formy prezentacji wyników.

W chwili obecnej dostępna jest bardzo szeroka oferta urządzeń do badań emisji otoakustycznych. Dodatkowo część systemów występuje w kilku różnych wariantach licencyjnych. Tak duża różnorodność opcji umożliwia wybór rozwiązania dokładnie dopasowanego do potrzeb wynikających z przeznaczenia i oczekiwanej funkcjonalności urządzenia.

Artykuł powstał $w$ zwiazku $z$ realizacja projektu „Zintegrowany system narzędzi do diagnostyki i telerehabilitacji schorzeń narzadów zmysłów (słuchu, wzroku, mowy, równowagi, smaku, powonienia)" wspótfinansowanego przez Narodowe Centrum Badań $i$ Rozwoju w ramach Programu STRATEGMED.

Tabela 1. Funkcje wybranych systemów do rejestracji OAE

Table 1. Functions of chosen systems for the OAE registration

\begin{tabular}{ll}
\hline \multicolumn{1}{c}{ System } & \multicolumn{1}{c}{ Możliwe badania } \\
\hline Madsen Alpha & DPOAE \\
\hline Madsen Accuscreen & TEOAE, DPOAE, ABR \\
\hline Madsen Capella ${ }^{2}$ & TEOAE, DPOAE, SEOAE \\
\hline GSI Corti & TEOAE, DPOAE \\
\hline GSI AudioScreener+ & TEOAE, DPOAE, ABR \\
\hline GSI Audera & DPOAE, SOAE, AEP (ECOChG, ABR, MLR, LLR), ASSR \\
\hline SmartScreener-Plus 2 & TEOAE, DPOAE, ABR \\
\hline SmartDPOAE & DPOAE \\
\hline
\end{tabular}


Trzaskowski B: Przegląd możliwości pomiarowych wybranych systemów...

\begin{tabular}{|c|c|}
\hline System & Możliwe badania \\
\hline SmartTrOAE & TEOAE \\
\hline OtoRead & TEOAE, DPOAE \\
\hline Eclipse & TEOAE, DPOAE, AEP (ABR, MLR, LLR, P300, MMN, ECochG, eABR), ASSR, VEMP \\
\hline Titan & TEOAE, DPOAE, AABR, IMP \\
\hline EchoLab & TEOAE, DPOAE, ABR, AABR \\
\hline EROSCAN Plus & TEOAE, DPOAE \\
\hline EROSCAN Pro & TEOAE, DPOAE, TYMP, REFLEX \\
\hline OtoStat & DPOAE, MEPA \\
\hline HearID & TEOAE, DPOAE, SFOAE, MEPA, MOCR \\
\hline AuDX Pro, AuDX Pro II, AuDX Pro Plus & TEOAE, DPOAE \\
\hline Echo-Screen III & TEOAE, DPOAE, ABR \\
\hline ABaer & TEOAE, DPOAE, ABR \\
\hline Neuro-Audio-Screen & TEOAE, DPOAE, ABR \\
\hline Neuro-Audio & TEOAE, DPOAE, SOAE, AEP (ABR, MLR, LLR, P300, MMN, ECochG), ASSR, VEMP, PTA \\
\hline Echoport ILO288 -I, Echoport ILO288 -II & ILO288-I: TEOAE; ILO288-II: TEOAE, DPOAE \\
\hline Echoport ILO292-I, Echoport ILO292-II & TEOAE, DPOAE, SOAE \\
\hline Otoport OAE+ABR (Upgrade) & TEOAE, DPOAE, ABR \\
\hline Otoport DP+TE OAE+ABR & TEOAE, DPOAE, ABR \\
\hline Otoport Lite OAE+ABR & TEOAE, DPOAE, ABR \\
\hline Otoport Advance & TEOAE, DPOAE \\
\hline Otoport DP+TE & TEOAE, DPOAE \\
\hline Otoport Lite & TEOAE lub DPOAE \\
\hline Otoport Screener & TEOAE \\
\hline Otocheck LE & TEOAE lub DPOAE \\
\hline Sentiero Desktop & TEOAE, DPOAE, PTA, SPEECH, TYMP, REFLEX \\
\hline Integrity V500 & TEOAE, DPOAE, ABR, ASSR, ECochG, ERP-40Hz \\
\hline
\end{tabular}

Tabela 2. Możliwości pomiarowe DPOAE i TEOAE wybranych systemów do rejestracji OAE

Table 2. DPOAE and TEOAE measurement capabilities of chosen systems for the OAE registration

\begin{tabular}{|c|c|c|}
\hline System & DPOAE & TEOAE \\
\hline Madsen Alpha & $\begin{array}{l}\text { Badane częstotliwości: 5, 4, } 3 \text { i } 2 \mathrm{kHz} \\
\text { Bodziec: para tonów, F2/F1=1,24 } \\
\text { Dostępne częstotliwości badane: } \mathrm{F} 2=2,3,4 \\
\text { i } 5 \mathrm{kHz} \\
\text { Domyślne częstotliwości badane: } \mathrm{F} 2=2,3,4 \\
\text { i } 5 \mathrm{kHz} \text { (PASS przy } 3 \text { z 4) } \\
\text { Domyślny poziom: L1/L2=65/55 dB SPL } \\
\text { SNR: } 6-8 \mathrm{~dB} \\
\text { Minimalna amplituda: }-5 \mathrm{~dB}\end{array}$ & \\
\hline Madsen Accuscreen & $\begin{array}{l}\text { Dostępne częstotliwości: konfigurowalne, } \\
\text { F2 w zakresie od } 1 \text { do } 6 \mathrm{kHz} \\
\text { Bodziec: para tonów, F2/F1=1,24 } \\
\text { Dostępne są } 4 \text { różne protokoły różniące się } \\
\text { częstotliwościami oraz kryteriami PASS/REFER. } \\
\text { Protokół domyślny: } 5,4,3,2 \mathrm{kHz} \text { (PASS przy } 3 \\
\text { z 4) } \\
\text { Poziom: L1/L2=60/50 lub } 65 / 55 \mathrm{~dB} \text { SPL }\end{array}$ & $\begin{array}{l}\text { Zakres częstotliwości: od } 1,5 \text { do } 4,5 \mathrm{kHz} \\
\text { Metoda szacowania: uśrednianie ważone } \\
\text { w zależności od szumu, zliczanie istotnych pików } \\
\text { W sygnale } \\
\text { Bodziec: nieliniowa sekwencja trzasków } \\
\text { Natężenie bodźca: } 70-84 \mathrm{~dB} \text { SPL ( } 45-60 \mathrm{~dB} \mathrm{HL} \text { ), } \\
\text { automatyczna kalibracja zależna od objętości kanału } \\
\text { słuchowego } \\
\text { Częstość podawania bodźca: ok. } 60 \mathrm{~Hz}\end{array}$ \\
\hline
\end{tabular}




\begin{tabular}{|c|c|c|}
\hline System & DPOAE & TEOAE \\
\hline Madsen Capella² & $\begin{array}{l}\text { Zakres częstotliwości: } 500-10000 \mathrm{~Hz} \\
\text { Krok zmiany częstotliwości: } 1 \mathrm{~Hz} \\
\text { Poziom: 0-75 dB SPL (w zależności od } \\
\text { częstotliwości) } \\
\text { Krok zmiany poziomu: } 1 \mathrm{~dB} \\
\text { Czas akwizycji: } 204,27 \mathrm{~ms} \\
\text { Rozdzielczość A/C: } 16 \text { bit } \\
\text { Kryterium SNR: Wybór przez użytkownika } \\
\text { Istnieje możliwość ręcznego konfigurowania } \\
\text { kombinacji badanych częstotliwości, } \\
\text { zapewniając praktycznie nieskończoną liczbę } \\
\text { punktów pomiarowych na oktawę }\end{array}$ & $\begin{array}{l}\text { Trzask i krótkie tony } \\
\text { Poziomy: } 40-90 \mathrm{~dB} \text { SPL } \\
\text { Zakres częstotliwości: } 450-5000 \mathrm{~Hz} \\
\text { Częstość odświeżania: wybór przez użytkownika } \\
\text { Kryterium SNR: } \\
\text { - wybór przez użytkownika } \\
\text { - korelacja i SNR (na pasmo, illub całkowita) }\end{array}$ \\
\hline GSI Corti & 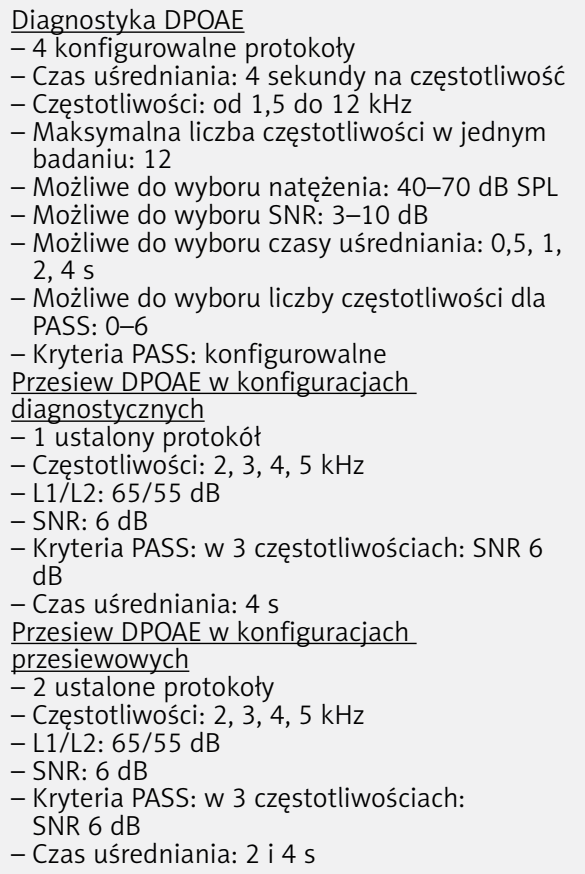 & $\begin{array}{l}\text { Diagnostyka TEOAE } \\
\text { - } 2 \text { konfigurowalne protokoły } \\
\text { - Częstotliwości: od 0,7 do } 4 \mathrm{kHz} \\
\text { - Możliwe do wyboru SNR: } 3-10 \mathrm{~dB} \\
\text { - Możliwe do wyboru czasy uśredniania: } 8,16,32 \\
\text { i } 64 \mathrm{~s} \\
\text { - Możliwe do wyboru liczby częstotliwości dla PASS: } \\
\text { 0-6 } \\
\text { - Kryteria PASS: konfigurowalne } \\
\text { Przesiew TEOAE w konfiguracjach diagnostycznych } \\
\text { - } 1 \text { ustalony protokót } \\
\text { - Pasma częstotliwości: } 1,5,2,2,5,3,3,5,4 \mathrm{kHz} \\
\text { - SNR: } 4 \mathrm{~dB} \\
\text { - Kryteria PASS: w } 3 \text { częstotliwościach: SNR } 4 \mathrm{~dB} \\
\text { - Maksymalny czas uśredniania: } 64 \mathrm{~s} \\
\text { Przesiew TEOAE w konfiguracjach przesiewowych } \\
\text { - } 2 \text { ustalone protokoty } \\
\text { - Pasma częstotliwości: } 1,5,2,2,5,3,3,5,4 \mathrm{kHz} \\
\text { - SNR: } 4 \text { dB } \\
\text { - Kryteria PASS: } \text { w } 3 \text { częstotliwościach: SNR } 4 \mathrm{~dB} \\
\text { - Maksymalny czas uśredniania: } 32 \mathrm{i} 64 \mathrm{~s}\end{array}$ \\
\hline GSI AudioScreener+ & $\begin{array}{l}\text { Zakres częstotliwości: od } 2000 \text { do } 6000 \mathrm{~Hz} \pm 2 \% \\
\text { Rozdzielczość w częstotliwości: } 50 \mathrm{~Hz} \\
\text { Dokładność pomiaru poziomu: } \pm 1 \mathrm{~dB} \mathrm{SPL} \\
\text { Zakres dynamiki: } 96 \mathrm{~dB} \\
\text { Czas badania: różni się w zależności od } \\
\text { wybranych parametrów } \\
\text { Zautomatyzowane kryteria PASS: DPOAE SNR } \\
\text { i/lub poziom DPOAE }\end{array}$ & $\begin{array}{l}\text { Zakres częstotliwości: od } 250 \text { do } 5250 \mathrm{~Hz} \pm 2 \% \\
\text { Rozdzielczość w częstotliwości: } 50 \mathrm{~Hz} \\
\text { Dokładność pomiaru poziomu: } \pm 1 \mathrm{~dB} \mathrm{SPL} \\
\text { Zakres dynamiki: } 96 \mathrm{~dB} \\
\text { Czas badania: różni się w zależności od wybranych } \\
\text { parametrów } \\
\text { Zautomatyzowane kryteria PASS: TEOAE SNR } \\
\text { i powtarzalność TEOAE }\end{array}$ \\
\hline GSI Audera & $\begin{array}{l}\text { Zakres częstotliwości: } 500-12000 \mathrm{~Hz} \\
\text { Poziom: } 20-80 \mathrm{~dB} \text { SPL, w } 5 \mathrm{~dB} \text { krokach, } \\
\text { dokładność: } \pm 3 \mathrm{~dB} \\
\text { Zakres dynamiczny: } 85 \mathrm{~dB} \text { SPL } \\
\text { F1 i F2=65 dB SPL } \\
\text { Zakresy oktaw: } 500-1000,1000-2000, \\
\text { 2000-4000, 4000-8000, 8000-12000 Hz } \\
\text { Punktów na oktawę: } 1-12 \text { punktów } \\
\text { Stosunek F2/F1: } 1,1-1,8\end{array}$ & \\
\hline $\begin{array}{l}\text { SmartDPOAE / } \\
\text { SmartTrOAE }\end{array}$ & $\begin{array}{l}\text { Parametry badania i kryteria zatrzymania } \\
\text { wybierane przez użytkownika } \\
\text { Zakres częstotliwości: } 500-8000 \mathrm{~Hz} \\
\text { Liczba częstotliwości na oktawę: } 3 \text { lub więcej } \\
\text { Stosunek częstotliwości F2/F1: } 1,22 \\
\text { Liczba pojedynczych rejestracji: } 16 \text { na } \\
\text { częstotliwość } \\
\text { Poziom: } 65 \text { dB SPL maksymalnie dla L1 i } 55 \text { dB } \\
\text { SPL dla L2 } \\
\text { Kryteria na PASS: } 65 \% \text { lub więcej } \\
\text { Konfiguracja wyświetlania zakresów } \\
\text { normatywnych. }\end{array}$ & 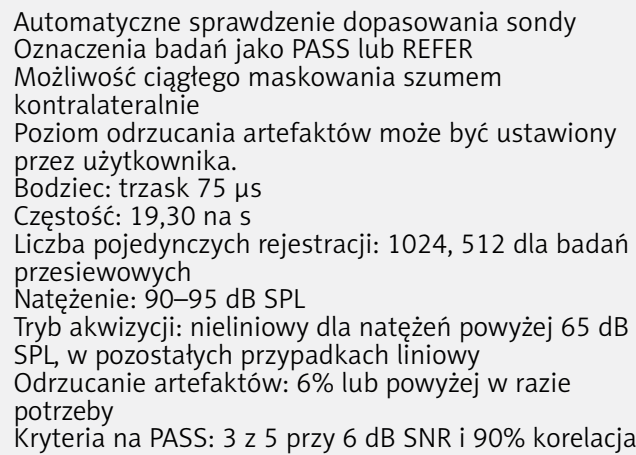 \\
\hline
\end{tabular}




\begin{tabular}{|c|c|c|}
\hline System & DPOAE & TEOAE \\
\hline OtoRead & $\begin{array}{l}\text { Różne protokoły w zależności od wybranego } \\
\text { wariantu z czterech możliwych licencji. } \\
\text { Screener + lub Screener DP (Ustalone protokoty) } \\
\text { Częstotliwości od } 2 \text { do } 5 \mathrm{kHz} \\
\text { - 4 częstotliwości badane ( } 3 \text { dla PASS) } \\
\text { - Średni czas badania: } 10 \text { lub } 15 \mathrm{~s} \\
\text { - SNR } 6 \mathrm{~dB} \\
\text { Standard DP lub Clinical DP\&TE } \\
\text { Ustawiane przez użytkownika: poziomy bodźca, } \\
\text { SNR, średni czas badania, liczba częstotliwości } \\
\text { dla PASS } \\
\text { Różne częstotliwości do wyboru pomiędzy } \\
1,5-12 \mathrm{kHz}\end{array}$ & $\begin{array}{l}\text { Różne protokoły w zależności od wybranego } \\
\text { wariantu z czterech możliwych licencji } \\
\text { Screener + lub Screener TE (Ustalone protokoły) } \\
\text { TE od } 1,5 \text { do } 4 \mathrm{kHz} \\
\text { - } 6 \text { częstotliwości badanych (3 dla PASS) } \\
\text { - Średni czas testu: } 12 \mathrm{~s} \\
\text { - SNR } 4 \mathrm{~dB} \\
\text { Standard TE lub Clinical DP\&TE } \\
\text { Ustawiane przez użytkownika: poziomy bodźca, SNR, } \\
\text { średni czas badania, liczba częstotliwości dla PASS } \\
\text { Różne częstotliwości do wyboru pomiędzy 0,7-4 kHz }\end{array}$ \\
\hline Eclipse & $\begin{array}{l}\text { DP-gramy dla protokołów predefiniowanych } \\
\text { przez użytkowników. Możliwość tworzenia } \\
\text { własnych zbiorów danych normatywnych } \\
\text { lub korzystania z norm dostarczonych przez } \\
\text { Interacoustics } \\
\text { Poziom bodźca: } 30-75 \mathrm{~dB} \mathrm{SPL} \text { (70 dB dla } \\
\text { częstotliwości powyżej } 6 \mathrm{kHz}) \\
\text { Zakres częstotliwości bodźca: } 500-8000 \mathrm{~Hz} \\
\text { Czas badania: } 2 \mathrm{~s}-\text { nieograniczony } \\
\text { Opcja wyświetlenia danych normatywnych } \\
\text { Protokoły definiowane przez użytkownika } \\
\text { Ręczne nadpisanie długości badania }\end{array}$ & $\begin{array}{l}\text { Poziom bodźca: } 50-90 \mathrm{~dB} \text { SPL } \\
\text { Bodziec: liniowy lub nieliniowy szerokopasmowy } \\
\text { trzask } \\
\text { Szerokość pasma bodźca: } 400-4000 \mathrm{~Hz} \\
\text { Czas badania: } 25-32000 \text { poj. rejestracji } \\
\text { Wyświetlanie: FFT, } 1 \mathrm{kHz} \text { pasm PASS/REFER, 1/3, 1/6, } \\
1 / 12 \text { oktawowych pasm, SNR, poziomu OAE } \\
\text { Automatyczny algorytm przesiewowy (wsk. PASS/ } \\
\text { REFER) lub algorytm definiowany przez użytkownika }\end{array}$ \\
\hline Titan & $\begin{array}{l}\text { Badania przesiewowe: } \\
\text { Zakres częstotliwości: } 500-6000 \mathrm{~Hz} \\
\text { Liczba badanych częstotliwości: maksymalnie } 6 \\
\text { na badanie } \\
\text { DP-gram } \\
\text { DPOAE pod ciśnieniem (opcjonalne), włączenie } \\
\text { PASS/REFER, dane normatywne (możliwa } \\
\text { edycja), protokoły definiowane przez } \\
\text { użytkownika } \\
\text { Badania kliniczne: } \\
\text { Zakres częstotliwości: } 500-10000 \mathrm{~Hz} \\
\text { Liczba badanych częstotliwości: nieograniczona } \\
\text { DP-gram, DP Input/Output } \\
\text { DPOAE pod ciśnieniem, włączenie PASS/ } \\
\text { REFER, dane normatywne (możliwa edycja), } \\
\text { badanie ręczne (dodawanie punktów badanych, } \\
\text { rozszerzenie badań), protokoły definiowane } \\
\text { przez użytkownika }\end{array}$ & $\begin{array}{l}\text { Badania przesiewowe: } \\
\text { Zakres częstotliwości 1000-4500 Hz } \\
\text { Czas badania: maksymalnie } 6 \text { minut lub } 4500 \\
\text { pojedynczych rejestracji } \\
\text { Natężenie bodźca: } 60-84 \mathrm{~dB} \text { SPL } \\
\text { Częstotliwości środkowe pasm: } 1,1,5,2,3,4 \mathrm{kHz} \\
\text { TEOAE pod ciśnieniem (opcjonalne), włączenie } \\
\text { PASS/REFER, dane normatywne (możliwa edycja), } \\
\text { rozszerzone badania, protokoły definiowane przez } \\
\text { użytkownika } \\
\text { Badania kliniczne: } \\
\text { Zakres częstotliwości: } 500-5500 \mathrm{~Hz} \\
\text { Czas badania: nieograniczony } \\
\text { Natężenie bodźca: } 30-90 \mathrm{~dB} \text { SPL } \\
\text { Czesstotliwości środkowe pasm: } 1,1,5,2,3,4 \mathrm{kHz} \\
\text { Liniowe pasma częstotliwości: } 5 \text { pasm oktawowych } \\
\text { 0,5-5,5 kHz lub definiowane przez użytkownika } \\
\text { TEOAE pod ciśnieniem, włączenie PASS/REFER, dane } \\
\text { normatywne (możliwa edycja), rozszerzone badania, } \\
\text { protokoły definiowane przez użytkownika }\end{array}$ \\
\hline EchoLab & $\begin{array}{l}\text { Zakres częstotliwości: } 250-10000 \mathrm{~Hz} \\
\text { Rozdzielczość w częstotliwości: 5, 10, } 25 \mathrm{~Hz}- \\
\text { programowalny } \\
\text { Dokładność częstotliwości: 0,01\% } \\
\text { Natężenie bodźca: 0-90 dB } \\
\text { Dokładność poziomu bodźca: } \pm 2 \mathrm{~dB} \text { SPL } \\
\text { Zakres dynamiki: } 90 \mathrm{~dB} \text { SPL } \\
\text { Mikrofon: } 15 \mathrm{~dB} \text { SPL w } 1000 \mathrm{~Hz}, 20 \mathrm{~dB} \mathrm{SPL} \\
\text { w } 2000 \mathrm{~Hz} \\
\text { Automatyczna kalibracja }\end{array}$ & $\begin{array}{l}\text { Bodźce liniowe i nieliniowe } \\
\text { Zakres częstotliwości: } 1000-5000 \mathrm{~Hz} \\
\text { Rozdzielczość częstotliwości: } 50 \mathrm{~Hz} \\
\text { Dokładność częstotliwości: } \pm 0,01 \% \\
\text { Poziom bodźca: 0-90 dB SPL } \\
\text { Dokładność poziomu bodźca: } \pm 2 \mathrm{~dB} \text { SPL } \\
\text { Zakres dynamiki: } 90 \mathrm{~dB} \text { SPL } \\
\text { Mikrofon: } 15 \mathrm{~dB} \text { SPL w } 1000 \mathrm{~Hz}, 20 \mathrm{~dB} \text { SPL } \\
\text { w } 2000 \mathrm{~Hz} \\
\text { Automatyczna kalibracja }\end{array}$ \\
\hline EROSCAN Plus & $\begin{array}{l}\text { Wersja przesiewowa: } \\
\text { Przesiewowe DPOAE } \\
2 \text { stałe protokoty (2/4 s) } \\
\text { Częstotliwości: } 2-5 \mathrm{kHz} \\
\text { PASS: } 3 \text { z } 4 \text { częstotliwości } \\
\text { Intensywność: } 65 / 55 \mathrm{~dB} \\
\text { SNR: } 6 \mathrm{~dB} \\
\text { Wersja diagnostyczna: } \\
\text { Przesiewowe DPOAE } \\
1 \text { ustalony protokół }(4 \mathrm{~s}) \\
\text { Częstotliwości: } 2-5 \mathrm{kHz} \\
\text { PASS: } 3 \text { z } 4 \text { częstotliwości } \\
\text { Intensywnośc: } 65 / 55 \mathrm{~dB} \\
\text { SNR: } 6 \mathrm{~dB} \\
\text { Diagnostyczne DPOAE } \\
\text { protokoty konfigurowalne } \\
\text { Częstotliwości: } 1,5-12 \mathrm{kHz} \\
\text { Częstotliwości dla PASS: } 0-6 \\
\text { Intensywność: } 40-70 \mathrm{~dB} \mathrm{SPL} \\
\text { SNR: } 3-10 \text { dB } \\
\text { Czas uśredniania: } 0,5,1,2,4 \mathrm{~s}\end{array}$ & $\begin{array}{l}\text { Wersja przesiewowa: } \\
\text { Przesiewowe TEOAE } \\
2 \text { stałe protokoły (32/64 s) } \\
\text { Częstotliwości: } 1,5-4 \mathrm{kHz} \\
\text { PASS: } 3 \text { z } 6 \text { częstotliwości } \\
\text { Intensywność: } 83 \mathrm{~dB} \text { SPL } \\
\text { SNR: } 4 \text { dB } \\
\text { Wersja diagnostyczna: } \\
\text { Przesiewowe TEOAE } \\
1 \text { ustalony protokół (64 s) } \\
\text { Częstotliwości: } 1,5-4 \mathrm{kHz} \\
\text { PASS: } 3 \text { z } 6 \text { częstotliwości } \\
\text { Intensywnośc: } 83 \mathrm{~dB} \text { SPL } \\
\text { SNR: } 4 \text { dB } \\
\text { Diagnostyczne TEOAE } \\
\text { 2 konfigurowalne protokoły } \\
\text { Częstotliwości: } 0,7-4 \mathrm{kHz} \\
\text { Częstotliwości dla PASS: } 0-6 \\
\text { Intensywność: } 83 \mathrm{~dB} \text { SPL } \\
\text { SNR: } 3-10 \text { dB } \\
\text { Czas uśredniania: } 8,16,32,64 \mathrm{~s}\end{array}$ \\
\hline
\end{tabular}


System

EROSCAN Pro
DPOAE

TEOAE

\begin{tabular}{|c|c|c|}
\hline EROSCAN Pro & $\begin{array}{l}\text { Wersja przesiewowa: } \\
\text { Badania przesiewowe DPOAE } \\
\text { 2 stałe protokoty (2/4 s) } \\
\text { Zakres czesstotliwości: } 2-5 \mathrm{kHz}, \\
\text { Liczba częstotliwości: } 4 \\
\text { PASS: } 3 \text { z } 4 \text { czesstotliwości } \\
\text { Intensywność: } 65 / 55 \mathrm{~dB} \text { SPL } \\
\text { SNR: } 6 \mathrm{~dB} \\
\text { Wersja diagnostyczna } \\
\text { Standardowe badania DPOAE } \\
\text { Liczba protokotów badań: } 20 \\
4 \text { protokoty konfigurowalne } \\
\text { Zakres częstotliwości: } 1,5-12 \mathrm{kHz} \\
\text { Liczba częstotliwości: } 10 \\
\text { Częstotliwości dla PASS: } 0-6 \\
\text { Intensywność: } 40-70 \mathrm{~dB} \text { SPL } \\
\text { SNR: } 3-10 \text { dB } \\
\text { Czas uśredniania: } 0,5,1,2,4 \mathrm{~s} \\
\text { Przesiewowe badania DPOAE } \\
1 \text { ustalony protokót (4 S) } \\
\text { Zakres częstotliwości: } 2-5 \mathrm{kHz} \\
\text { PASS: } 3 \text { z } 4 \text { czesstotliwości } \\
\text { Intensywność: } 65 / 55 \mathrm{~dB} \text { SPL } \\
\text { SNR: } 6 \mathrm{~dB}\end{array}$ & 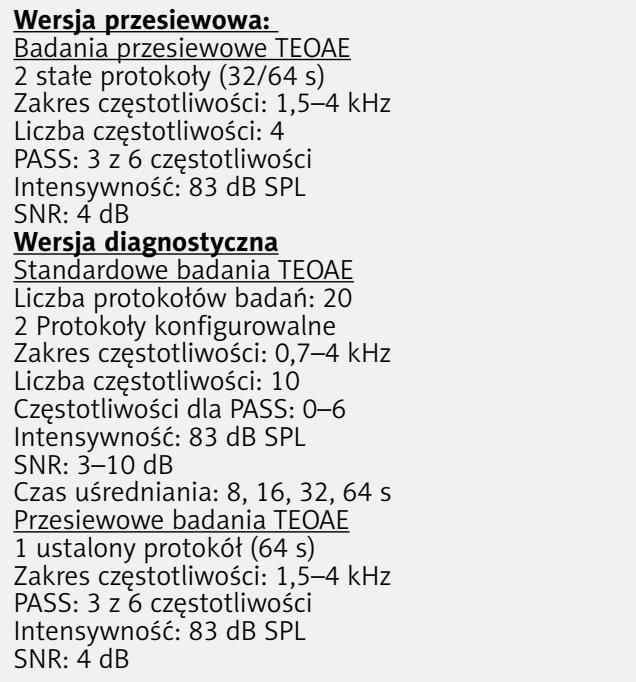 \\
\hline OtoStat & $\begin{array}{l}\text { Zasady zatrzymania dla obu wyników PASS/ } \\
\text { REFER. } \\
\text { Zakres częstotliwości: } 1000-8000 \mathrm{~Hz} \\
\text { Poziom L1/L2: } 65 / 55 \mathrm{~dB} \text { SPL } \\
\text { Stosunek f2/f1: } 1,2 \\
\text { Czas testu na częstotliwość: } 2 \text { do } 6 \text { sekund } \\
\text { Pomiary DPOAE: 2f1-f2 } \\
3 \text { protokoły kliniczne, wykorzystujące 4, } 6 \text {, lub } \\
12 \text { częstotliwości testowych } \\
\text { Normy dla każdej grupy wiekowej }\end{array}$ & \\
\hline HearlD & $\begin{array}{l}\text { Zakres częstotliwości: } 500-16000 \mathrm{~Hz} \\
\text { Liczba badanych punktów na oktawę: } 1-50 \\
\text { Zakres poziomu: } 0-70 \mathrm{~dB} \text { SPL } \\
\text { Stosunek F2/F1: } 1,1-1,8 \\
\text { Odrzucenie artefaktów } \\
\text { Zasady zatrzymania } \\
\text { Zdefiniowane punkty DP: f2-f1; 2f2-f1; 2f1-f2; } \\
\text { 3f1-2f2; 3f2-2f1; } 4 \mathrm{f} 1-3 \mathrm{f2} 2 \text {; } 4 \mathrm{f2}-3 \mathrm{ff} \text {. } \\
\text { Zaprogramowane protokoły pomiarów dla } 4 \\
\text { i } 6 \text { częstotliwości protokotów Boystown i } 6 \\
\text { i } 12 \text { testów częstotliwości dla wygodnego } \\
\text { zestawienia. } \\
\text { Konfigurowalne protokoły pomiarów } \\
\text { Dane normatywne }\end{array}$ & $\begin{array}{l}\text { Tryby badawczy i kliniczny } \\
\text { Zaprogramowane protokoty pomiarów } \\
\text { Typy bodźca: prostokątny trzask, dwufazowy } \\
\text { prostokątny trzask, trzask Gaussa, differentiated } \\
\text { Gaussian click, flat group-delay chirp, linear group- } \\
\text { delay chirp, Dau group-delay chirp, Shera group-delay } \\
\text { chirp } \\
\text { Konfigurowalne: szerokość pasmowa bodźca, } \\
\text { czas trwania, poziom, białe lub różowe widmo, } \\
\text { polaryzacja. } \\
\text { Regulowany odstęp pomiędzy bodźcami. Liniowe } \\
\text { i nieliniowe tryby podawania bodźca } \\
\text { Regulowane filtry dolno- i górnoprzepustowe } \\
\text { odpowiedzi TEOAE. Regulowane okno odpowiedzi } \\
\text { TEOAE } \\
\text { Regulowany poziom odrzucania szumu oraz } \\
\text { opcjonalny tryb automatyczny. } \\
\text { Kalibracji sondy w uchu, opcja kompensacji widma } \\
\text { Wyraźne wskazanie wyniku PASS/REFER i możliwość } \\
\text { ich konfiguracji przez użytkownika } \\
\text { Zasady zatrzymania zakończają test wcześniej przy } \\
\text { osiągnięciu wyniku PASS. Zasady szerokopasmowe } \\
\text { i wąskopasmowe mogą być konfigurowane } \\
\text { indywidualnie }\end{array}$ \\
\hline ABaer & $\begin{array}{l}\text { Przesiewowe badanie w zakresie częstotliwości: } \\
2,3,4 \text { i } 5 \mathrm{kHz} \\
\text { Szybki czas badania - około } 10 \text { sekund na ucho } \\
\text { Wewnątrzuszna kalibracja bodźca i sprawdzenie } \\
\text { stabilizacji sondy przed badaniem }\end{array}$ & $\begin{array}{l}\text { Zakres częstotliwości testowanych: } 1,2 \text { do } 3,5 \mathrm{kHz} \\
\text { Krótkie czasy badań - około } 10 \text { sekund na ucho } \\
\text { Kontrola stabilności sondy równocześnie podczas } \\
\text { całego badania ucha }\end{array}$ \\
\hline $\begin{array}{l}\text { Echoport ILO288-I, } \\
\text { Echoport ILO288-II }\end{array}$ & $\begin{array}{l}\text { DPOAE tylko w modelu ILO288-II } \\
1 \text {-8 kHz DPOAE } \\
\text { Wybierane przez użytkownika poziomy bodźców } \\
\text { i liczba punktów na oktawę } \\
\text { DP-gram (tylko w ILO288-II) - do wyboru przez } \\
\text { użytkownika poziom bodźców i punktów na } \\
\text { oktawę w tym wysokiej rozdzielczości DP-gram } \\
\text { do } 8 \text { punktów (wyświetlane } 27 \text { częstotliwości) }\end{array}$ & $\begin{array}{l}\text { Półoktawowy histogram częstotliwości } \\
\text { przedstawiający OAE i szum } \\
1-4 \mathrm{kHz} \text { TEOAE } \\
\text { Pasmowe wskaźniki PASS oparte na kryteriach } \\
\text { Zapis przebiegu TEOAE i widok widma } \\
\text { TEOAE Quickscreen - do badań przesiewowych lub } \\
\text { do badań klinicznych w połączeniu z DPOAE } \\
\text { - konfigurowalny poziom bodźców typu trzask }\end{array}$ \\
\hline
\end{tabular}




\section{System}

Echoport ILO292-I, Echoport ILO292-I
DPOAE

TEOAE

\begin{tabular}{|c|c|c|}
\hline & $\begin{array}{l}\text { OKtawę } \\
\text { Wstępnie ustawione lub konfigurowalne bodźce } \\
\text { Programowalne poziomy L1 i L2, częstość, } \\
\text { punkty/oktawę, zakres częstotliwości } \\
\text { Ręczna/automatyczna/inteligentna zmiana } \\
\text { częstotliwości, analiza DP I/O } \\
\text { Jednoczesna obustronna rejestracja dla Echoport } \\
\text { ILO292-II } \\
\text { Ocena całkowitej mocy DP. Rzeczywiste } \\
\text { uśrednianie w dziedzinie czasu i statystyki } \\
\text { szumu } \\
\text { Wyświetlanie pełnego widma podczas badania } \\
\text { DPOAE obejmuje DPOAE wyższego rzędu }\end{array}$ & $\begin{array}{l}\text { Bodźce typu trzask lub konfigurowalny impuls } \\
\text { tonalny } \\
\text { Regulowana intensywność stymulacji, kalibracja } \\
\text { w uchu } \\
\text { Monitorowanie w czasie rzeczywistym bodźca } \\
\text { i dopasowania sondy } \\
\text { Analiza ILO dająca poziomy OAE w dB SPL i parametr } \\
\text { powtarzalności w półoktawowych pasmach } \\
\text { częstotliwości } \\
\text { Jednoczesna obustronna rejestracja dla Echoport } \\
\text { ILO292-II }\end{array}$ \\
\hline $\begin{array}{l}\text { Otoport OAE+ABR } \\
\text { (Upgrade) }\end{array}$ & $\begin{array}{l}\text { 1-8 kHz DP-gram, } 12 \text { częstotliwości } \\
\text { (konfigurowalne) } \\
1-8 \mathrm{kHz} 4 \text { pkt/oktawę - DP-gram } \\
\text { Zoptymalizowany tryb pediatryczny. } \\
\text { Wyświetlanie w trybie PASS/REFER lub } \\
\text { szczegółowe }\end{array}$ & $\begin{array}{l}\text { 1-4 kHz TEOAE ILO QuickScreen } \\
\text { Zoptymalizowany tryb pediatryczny. Wyświetlanie } \\
\text { w trybie PASS/REFER lub szczegółowe }\end{array}$ \\
\hline Otoport DP+TE OAE+ABR & $\begin{array}{l}\text { Szybkie zautomatyzowane badania } \\
\text { przesiewowe DPOAE } \\
\text { Automatyczna analiza dopasowania sondy } \\
\text { i poziomu szumu } \\
\text { Konfigurowalne kryteria PASS } \\
2,3,4 \text { lub } 5 \text { częstotliwości PASS w DPOAE } \\
\text { Histogram sygnału i szumu ze wskaźnikami } \\
\text { PASS w pasmach } \\
\text { Konfigurowalny } 12 \text { punktowy DP-gram 1-8 kHz } \\
\text { Cztery tryby testowe } \\
\text { Tylko w modelu Advance: analiza widmowa, } \\
\text { analiza DPOAE w powiększeniu, } 16 \text { pkt/oktawę } \\
\text { wzrost DP I/O growth i macro-multi test }\end{array}$ & $\begin{array}{l}\text { Szybkie zautomatyzowane badania przesiewowe } \\
\text { TEOAE } \\
\text { Automatyczna analiza dopasowania sondy i poziomu } \\
\text { szumu } \\
\text { Konfigurowalne kryteria PASS } \\
2,3 \text { lub } 4 \text { półoktawowe pasma PASS w TEOAE } \\
\text { Histogram sygnału i szumu ze wskaźnikami PASS } \\
\text { w pasmach } \\
\text { Cztery tryby testowe } \\
\text { TEOAE QuickScreen } 1-4 \mathrm{kHz} \\
\text { Zapis przebiegu TEOAE } \\
\text { Tylko w modelu Advance: analiza widmowa, TEOAE } \\
1-6 \mathrm{kHz} \text {, sześć półoktawowych pasm }\end{array}$ \\
\hline Otoport Lite OAE+ABR & $\begin{array}{l}\text { Funkcje DPOAE } \\
\text { - Automatyczne badania przesiewowe OAE } \\
\text { - Automatyczne dopasowanie sondy i analiza } \\
\text { hałasu } \\
\text { - Konfigurowalne kryteria PASS/REFER } \\
\text { - SNR dla 2, 3 lub } 4 \text { częstotliwości } \\
\text { - Tryb DPOAE 2-6 kHz, } 4 \text { częstotliwości }\end{array}$ & $\begin{array}{l}\text { Funkcje TEOAE } \\
\text { - Automatyczne badania przesiewowe OAE } \\
\text { - Automatyczne dopasowanie sondy i analiza hałasu } \\
\text { - Konfigurowalne kryteria PASS/REFER } \\
\text { - SNR dla 2, 3 lub } 4 \text { częstotliwości } \\
\text { - Tryb TEOAE 1-4 kHz, } 5 \text { pasm półoktawowych }\end{array}$ \\
\hline Otoport Advance & $\begin{array}{l}\text { DPOAE } \\
\text { - Zaawansowany DP-gram 1-8 kHz, 2-16 } \\
\text { pkt/oktawę, 1-13 częstotliwości } \\
\text { - Standardowy DP-gram } 6 \text { pkt, 1-8 kHz, } 2 \\
\text { pkt/oktawe } \\
\text { - Przybliżenie DP aż do pasma pótoktawowego } \\
\text { i do rozdzielczości } 16 \text { pkt/oktawe } \\
\text { - Programowalne bodźce DP f1 i f2, } \\
\text { 40-75 dBSPL } \\
\text { - Analiza funkcji wzrostu DP I/O } \\
\text { - Inteligentne lub ręczne zarządzanie do } \\
\text { szybkiego badania } \\
\text { TEOAE + DPOAE } \\
\text { - Programowalne makro badania } \\
\text { i automatyczna kontrola OAE } \\
\text { - Konfigurowalne wyświetlanie zakresu } \\
\text { markerów danych normatywnych } \\
\text { - Narzędzia odrzucania artefaktów } \\
\text { - 12 trybów badań, } 10 \text { w pełni } \\
\text { konfigurowalnych } \\
\text { - Sprawdzanie sondy w czasie rzeczywistym } \\
\text { i wyświetlanie dokładności }\end{array}$ & $\begin{array}{l}\text { TEOAE } \\
\text { - QuickScreen z analizą ILO } \\
\text { - Wyświetlanie przebiegu sygnału, dB SPL, SNR } \\
\text { i Repro } \\
\text { - Analiza częstotliwości: 1-6 kHz, } 6 \text { pasm, analiza } \\
\text { półoktawowa } \\
\text { - Widmo w wysokiej rozdzielczości (szerokość pasma } \\
80 \mathrm{~Hz} \text { ) } \\
\text { TEOAE + DPOAE } \\
\text { - Programowalne makro badania i automatyczna } \\
\text { kontrola OAE } \\
\text { - Konfigurowalne wyświetlanie zakresu markerów } \\
\text { danych normatywnych } \\
\text { - Narzędzia odrzucania artefaktów } \\
\text { - } 12 \text { trybów badań, } 10 \text { w pełni konfigurowalnych } \\
\text { - Sprawdzanie sondy w czasie rzeczywistym } \\
\text { i wyświetlanie dokładności }\end{array}$ \\
\hline
\end{tabular}




\begin{tabular}{|c|c|c|}
\hline System & DPOAE & TEOAE \\
\hline Otoport DP+TE & $\begin{array}{l}\text { 1-8 kHz DP-gram oraz } 12 \text { częstotliwości } \\
\text { (konfigurowalne) } \\
1-8 \text { kHz } 4 \text { pkt/oktawę DP-gram } \\
\text { Natychmiastowe DPOAE lub TEOAE wybór trybu } \\
\text { na początku badania } \\
\text { Tryby DP wysokiego bodźca i DP niskiego } \\
\text { bodźca, konfigurowalne poziomy } \\
\text { Tryb } 12 \text { częstotliwości DP dla wyższych } \\
\text { rozdzielczości badań } \\
\text { Konfigurowalne dowolne kryteria PASS DPOAE } \\
\text { dla 2, 3, } 4 \text { lub } 5 \text { częstotliwości } \\
\text { Opcja automatycznego startu dla szybkiego } \\
\text { testu przesiewowego } \\
\text { Tryb inteligentny zarządzania testem do } \\
\text { szybszego badania } \\
\text { Konfigurowalne odrzucanie szumu dla danego } \\
\text { otoczenia }\end{array}$ & $\begin{array}{l}\text { 1-4 kHz TEOAE ILO Quickscreen } \\
\text { Natychmiastowe DPOAE lub TEOAE wybór trybu na } \\
\text { początku badania } \\
\text { 2, } 3 \text { lub } 4 \text { półoktawowe, szeroko- lub } \\
\text { wąskopasmowe kryteria PASS dla TEOAE } \\
\text { Opcja automatycznego startu dla szybkiego testu } \\
\text { przesiewowego } \\
\text { Tryb inteligentny zarządzania testem do szybszego } \\
\text { badania } \\
\text { Konfigurowalne odrzucanie szumu dla danego } \\
\text { otoczenia }\end{array}$ \\
\hline Otoport Lite & $\begin{array}{l}\text { Dedykowany do badań przesiewowych } \\
\text { w pediatrii, częstotliwości 2--6 kHz, } 4 \text { punkty } \\
\text { Prosta obsługa „press-and-go”. Wyniki PASS/ } \\
\text { REFER } \\
\text { Szybki tryb odporny na hałas } \\
\text { Intuicyjny wyświetlacz graficzny pokazuje } \\
\text { zmiany SNR } \\
\text { Graficzne wskazanie dopasowania sondy } \\
\text { Alarmy dla złego dopasowania sondy lub } \\
\text { wysokiego poziomu szumu }\end{array}$ & $\begin{array}{l}\text { Przeznaczony do badań przesiewowych noworodków } \\
\text { Zakres: 1-4 kHz Quickscreen, } 84 \mathrm{~dB} \text { SPL, bodziec } \\
\text { nieliniowy, } 5 \text { pasm częstotliwości, } 3 \text { tryby kontroli } \\
\text { bezpieczeństwa } \\
\text { Prosta obsługa „press-and-go”. Wyniki PASS/REFER } \\
\text { Szybki tryb odporny na hałas } \\
\text { Intuicyjny wyświetlacz graficzny pokazuje zmiany } \\
\text { SNR } \\
\text { Graficzne wskazanie dopasowania sondy } \\
\text { Wybór wyświetlania całościowego lub pasm } \\
\text { częstotliwości } \\
\text { Alarmy dla złego dopasowania sondy lub wysokiego } \\
\text { poziomu szumu }\end{array}$ \\
\hline Otoport Screener & & $\begin{array}{l}\text { Badania przesiewowe TEOAE } \\
\text { TEOAE QuickScreen, 60-90 dB SPL, } 5 \text { częstotliwości, } \\
\text { zakres: } 1-4 \mathrm{kHz} \\
\text { Histogram TEOAE półoktawowy } \\
\text { Tabele numeryczne OAE } \\
4 \text { tryby przesiewowe z konfigurowalnymi } \\
\text { parametrami } \\
\text { Konfigurowalne kryteria zatrzymania i klasyfikacji } \\
\text { wyników }\end{array}$ \\
\hline Otocheck LE & $\begin{array}{l}\text { Model DPOAE przesiewowy dla dzieci } \\
\text { i młodzieży, 2-6 kHz, } 4 \text { punkty częstotliwości } \\
\text { Prosta obsługa w trybie „press-and-go” } \\
\text { Wyniki: PASS/REFER } \\
\text { Szybki tryb odporny na hałas } \\
\text { Intuicyjny wyświetlacz graficzny pokazuje } \\
\text { postęp SNR } \\
\text { Graficzne wskazania sondy (checkfit) }\end{array}$ & $\begin{array}{l}\text { Model TEOAE przesiewowy dla niemowląt, 1-4 kHz } \\
\text { QuickScreen, } 5 \text { pasm częstotliwości } \\
\text { Prosta obsługa w trybie „press-and-go” } \\
\text { Wyniki: PASS/REFER } \\
\text { Szybki tryb odporny na hałas } \\
\text { Intuicyjny wyświetlacz graficzny pokazuje postęp } \\
\text { SNR } \\
\text { Graficzne wskazania sondy (checkfit) } \\
\text { Wybór ogólnych wskazań lub dla pasm częstotliwości } \\
\text { w modelu TEOAE }\end{array}$ \\
\hline Sentiero Desktop & $\begin{array}{l}\text { Szybkie/diagnostyczne tryby testowe DPOAE: } \\
\text { - zakres: od } 1 \text { do } 10 \mathrm{kHz} \text {, wysokiej } \\
\text { rozdzielczości - do } 30 \text { punktów na oktawę } \\
\text { - wielokanałowa stymulacja oszczędza czas } \\
\text { - FM DPOAE - Frequency Modulated DPOAE } \\
\text { DPOAE - oszacowanie progu słuchu, } \\
\text { automatyczny audiogram ślimakowy do } 50 \mathrm{~dB} \\
\text { HL: } \\
\text { - poziom bodźców: od } 20 \mathrm{~dB} \mathrm{HL} \text { do } 65 \mathrm{~dB} \mathrm{HL} \\
\text { - zakres częstotliwości: od } 1,5 \mathrm{kHz} \text { do } 8 \mathrm{kHz}\end{array}$ & $\begin{array}{l}\text { Szybkie/diagnostyczne tryby testowe TEOAE: } \\
\text { - zakres: od 0,7 do } 4 \mathrm{kHz} \text {, szybki test/test } \\
\text { diagnostyczny z pasmami półoktawowymi } \\
\text { - wielokrotne kryteria zatrzymania } \\
\text { - możliwość ustawienia SNR }\end{array}$ \\
\hline Integrity V500 & $\begin{array}{l}\text { Diagnostyczne i automatyczne badania } \\
\text { przesiewowe DPOAE } \\
\text { Bodźce - częstotliwości F2: } 0,5,0,75,1,1,5,2 \text {, } \\
\text { 2,5, 3, 3,2, 3,5, 4, 4,5, 5, 5,5, 6, 7, } 8 \mathrm{kHz} \\
\text { Poziomy: 40-75 dB SPL, stosunek F2/F1: 1,2 } \\
\text { i 1,22 } \\
\text { Szum systemu i system DP: } \leq-10 \mathrm{~dB} \text { SPL przy } \\
\text { bodźcu 75/75 dB SPL } \\
\text { Zmienne mierzone: sygnał, szum, SNR na } \\
\text { częstotliwościach f2 } \\
\text { Kryteria PASS/REFER: wielokrotne, elastyczne, } \\
\text { do wyboru przez użytkownika } \\
\text { Kalibracja sondy } \\
\text { VivoLink automatycznie pobiera dane kalibracji } \\
\text { sondy OAE i wykonuje autotest systemu przed } \\
\text { rozpoczęciem badania, reguluje poziom bodźca } \\
\text { i wykonuje pomiary OAE }\end{array}$ & $\begin{array}{l}\text { Diagnostyczne i automatyczne badania przesiewowe } \\
\text { TEOAE } \\
\text { Bodźce: trzask } 80,120 \mu \mathrm{s}, 60-85 \mathrm{~dB} \text { pe SPL, liniowe, } \\
\text { nieliniowe } \\
\text { Mierzone wartości: sygnał, szum, SNR w } 1-\mathrm{kHz}, 1 \text {, } \\
1 / 2,1 / 4,1 / 6 \text {-oktawowych pasmach } \\
\text { Kryteria PASS/REFER: wielokrotne, elastyczne, do } \\
\text { wyboru przez użytkownika } \\
\text { Kalibracja sondy } \\
\text { VivoLink automatycznie pobiera dane kalibracji } \\
\text { sondy OAE i wykonuje autotest systemu przed } \\
\text { rozpoczęciem badania, reguluje poziom bodźca } \\
\text { i wykonuje pomiary OAE }\end{array}$ \\
\hline
\end{tabular}




\section{Piśmiennictwo:}

1. Kemp DT. Stimulated acoustic emissions from within the human auditory system. J Acoust Soc Am, 1978; 64(5): 1386-91.

2. Shera CA, Guinan JJ. Evoked otoacoustic emissions arise by two fundamentally different mechanisms: a taxonomy for mammalian OAEs. J Acoust Soc Am, 1999; 105: 782-98.

3. Knight RD, Kemp DT. Indications of different distortion product otoacoustic emission mechanisms from a detailed $\mathrm{f} 1, \mathrm{f} 2$ area study. J Acoust Soc Am, 2000; 107(1): 457-73.

4. Katz J. Handbook of Clinical Audiology. LWW; Seventh, North American Edition; 2014.

5. Strickland AE, Burns EM, Tubis A. Incidence of spontaneous otoacoustic emissions in infants and children. J Acoust Soc Am, 1985; 78: 931-35.

6. Talmadge CL, Long GR, Murphy WJ, Tubis A. New off-line method for detecting spontaneous otoacoustic emissions in human subjects. Hear Res, 1993; 71: 170-82.

7. Kemp DT. Evidence of mechanical nonlinearity and frequency selective wave amplification in the cochlea. Arch Otorhinolaryngol, 1979; 224(1-2): 37-45.

8. Kemp DT. The evoked cochlear mechanical response and the auditory microstructure - evidence for a new element in cochlear mechanics. Scand Audiol Suppl, 1979; 9: 35-47.

9. Zhang VW, McPherson B, Shi BX, Tang JL, Wong BY. Neonatal hearing screening: a combined click evoked and tone burst otoacoustic emission approach. Int J Pediatr Otorhinolaryngol, 2008; 72(3): 351-60.

10. Hatzopoulos S, Petruccelli J, Pelosi G, Martini A. A TEOAE screening protocol based on linear click stimuli: performance and scoring criteria. Acta Otolaryngol, 1999; 119(2): 135-39.

11. Keppler H, Dhooge I, Maes L, D’haenens W, Bockstael A, Philips B i wsp. Transient-evoked and distortion product otoacoustic emissions: A short-term test-retest reliability study. Int J Audiol, 2010; 49(2): 99-109.

12. Piłka E, Jędrzejczak WW, Trzaskowski B, Skarżyński H. Variability of distortion product otoacoustic emissions at 10, 12, and $16 \mathrm{kHz}$ : a preliminary study. JHS, 2014; 4(4): 59-64.

13. http: //www.otometrics.com/Screening/MADSEN-Alpha-OAE.

14. http: //www.otometrics.com/Screening/newborn-hearingscreening-madsen-accuscreen.

15. http: //www.otometrics.com/Hearing-assessment/otoacousticemissions-testing-oae-capella-2.

16. http: //www.grason-stadler.com/products/corti.

17. http: //www.grason-stadler.com/products/gsi-audioscreener/.
18. http: //www.grason-stadler.com/products/gsi-audera/.

19. http: //www.ihsys.com/site/SmartScreenerPlus.asp?tab $=0$.

20. http: //www.ihsys.com/site/SmartDPOAE.asp?tab=2.

21. http: //www.ihsys.com/site/SmartTrOAE.asp?tab=2

22. http: //www.interacoustics.com/otoread.

23. http: //www.interacoustics.com/eclipse.

24. http: //www.interacoustics.com/titan.

25. http: //www.labatinternational.com/international-products/ otoacoustic-emission/echolabs/.

26. http: //www.maico-diagnostic.com/products/oae/eroscan/.

27. http://www.maico-diagnostic.com/products/oae/ero-scan-pro/.

28. http: //www.mimosaacoustics.com/products/otostat.html.

29. http: //www.mimosaacoustics.com/products/hearid.html.

30. Shera CA, Guinan JJ. Evoked otoacoustic emissions arise by two fundamentally different mechanisms: a taxonomy for mammalian OAEs. J Acousti Soc Am, 1999; 105: 782-98.

31. Shera CA. Mechanisms of mammalian otoacoustic emission and their implications for the clinical utility of otoacoustic emissions. Ear Hear, 2004; 25: 86-97.

32. http: //www.natus.com/index.cfm?page=products_1\&crid=217.

33. http: //www.natus.com/index.cfm? page $=$ products_1\& $c r i d=967$.

34. http: $/ / w w w . n a t u s . c o m / i n d e x . c f m ?$ page $=$ products_1 $16 \mathrm{crid}=968$.

35. http: //www.natus.com/index.cfm?page=products_1\& crid=970.

36. http: //www.natus.com/index.cfm?page=products_1\&crid=19.

37. http: //www.neurosoft.ru/eng/product/neuro-audio-screen/index.aspx.

38. http: //www.neurosoft.ru/eng/product/neuro-audio-2010/index. aspx.

39. http: //otodynamics.com/product_info.asp?id=22.

40. http: //otodynamics.com/product_info.asp?id=130.

41. http: //otodynamics.com/product_info.asp?id=111.

42. http: //otodynamics.com/product_info.asp?id=129.

43. http: //www.otodynamics.com/product_otoport.asp.

44. http: //www.otodynamics.com/product_info.asp? $i d=246$.

45. http: //www.otodynamics.com/product info.asp? id $=300$.

46. http: //www.otodynamics.com/product_info.asp? $i d=301$.

47. http: //www.otodynamics.com/product_info.asp?id=322.

48. http: //otodynamics.com/product_info.asp?id=265.

49. http: //otodynamics.com/product_info.asp?id=323.

50. http: //otodynamics.com/product_info.asp?id=215.

51. http: //otodynamics.com/product_info.asp?id $=270$.

52. http: //www.pathme.de/index.php/en/products/sentiero-desktop.

53. http: //www.vivosonic.com/integrity-v500-system/. 